\title{
MONETARY STAGES AND FRAMEWORKS OF EMERGING EU MEMBERS
}

\author{
Emilija Beker Pucar* and Olgica Clavaski \\ Faculty of Economics in Subotica, University of Novi Sad, Novi Sad, The Republic of Serbia
}

The paper reviews the monetary stages and frameworks towards the eurozone (EZ) for emerging EU members. At the first pre-EU stage, three monetary frameworks were identified, whereas at the second preEZ stage, the emerging EU members combined ER targeting with the rigid/fixed exchange rate regimes (ERRs), on the one hand, and inflation targeting (IT) with the Exchange Rate Mechanism (ERM II), on the other. The last stage of monetary convergence assumes monetary nonautonomy within the monetary union as a rigid ERR, where the ER and monetary policies are sacrificed as countercyclical instruments. Countries with rigid ERRs are more prone to macroeconomic overheating, performing worse under a crisis impact compared to the floaters. The difficulties to maintain stability under a rigid ER environment, such as the monetary union, as well as the inherent vulnerabilities of the EZ, are crucial for the delayed entry of some EU members into the ERM II.

Keywords: eurozone, exchange rate mechanism, monetary convergence, adjustment mechanisms, monetary and exchange rate regimes

\section{JEL Classification: E52, F15, F45}

\section{INTRODUCTION}

New EU members do not automatically accept the euro after accessing the EU although they participate in the Economic and Monetary Union (EMU). The EMU assumes a gradual development of candidate countries (the convergence process) leading to the common currency at the end of the road. Bearing in mind the fact that all emerging EU countries

* Correspondence to: E. Beker Pucar, Faculty of Economics in Subotica, University of Novi Sad, ul. dr Sime Miloševića 16, 21000 Novi Sad, The Republic of Serbia;

e-mail:emilijab@ef.uns.ac.rs must adopt the euro sooner or later, the monetary authorities of emerging Europe are confronted with necessary changes in the exchange rate regimes (ERRs) and the monetary regimes. Basically, the three key stages could be identified in the process of monetary convergence towards the euro area (European Commission, 1998; De Grauwe \& Schnabl, 2004). The first stage includes the period until the EU entry; the second stage assumes the period between the EU entry and the adoption of the euro, while the third stage indicates participation in the eurozone (EZ). 
Emerging European economies (EEEs) chose a different ER and monetary strategies on the road towards the EU. On the one hand, countries choose an exchange-rate peg in different forms: the currency board, conventional pegs, intermediate exchangerate regimes (the group of fixers). The fixers adopted ER targeting as the monetary framework with a limited maneuvering space for the monetary policy. As another option, countries opted for the managed floating ERR and inflation targeting (IT) as the monetary framework (the floaters). This monetary path assumes a more flexible monetary policy since it is not constrained by a specific euro peg. While the first stage of monetary convergence allows autonomy in choosing an adequate monetary option, the second is, however, more limited since EU members should, sooner or later, accomplish the Maastricht convergence criteria, including the Exchange Rate
Mechanism (ERM II) target zone. The second stage of monetary convergence is a real challenge for the monetary authorities of the EEEs given the fact that nominal and real convergence are very difficult to reconcile within the ERM II target zone. The evolution of the ERRs and the monetary regimes of emerging EU members on the road towards the EZ in the period 1990-2018 is identified in Table 1 and Table 2.

EEEs should be well-prepared in terms of sustainable real and nominal convergence in order to for them to function under the constrained monetary environment in the ERM II. The ERM II target zone is a preparation for an even more rigid monetary environment within the EZ, bearing in mind the complete loss of monetary autonomy. These monetary switches are complex, especially with respect to the floaters who are accustomed to a higher ER

Table 1 The evolution of ERRs in the emerging EU members in the period 1990-2018

\begin{tabular}{|c|c|c|c|c|c|c|c|c|c|}
\hline $\begin{array}{c}\text { Country/ } \\
\text { ERR }\end{array}$ & $\begin{array}{c}\text { Currency } \\
\text { board }\end{array}$ & $\begin{array}{c}\text { Conventi- } \\
\text { onal fixed } \\
\text { ER }\end{array}$ & $\begin{array}{c}\text { Adjustable } \\
\text { peg }\end{array}$ & $\begin{array}{l}\text { Crawling } \\
\text { peg }\end{array}$ & $\begin{array}{c}\text { Crawling } \\
\text { corridor } \\
\text { or target } \\
\text { zone }\end{array}$ & $\begin{array}{l}\text { Managed } \\
\text { floating }\end{array}$ & $\begin{array}{l}\text { Free } \\
\text { floating }\end{array}$ & $\begin{array}{c}\text { Target } \\
\text { zone ERM } \\
\text { II }\end{array}$ & $\begin{array}{l}\text { Monetary } \\
\text { union (EZ) }\end{array}$ \\
\hline & Rigid ERR & \multicolumn{4}{|c|}{ Intermediate (hybrid) ERR } & \multicolumn{2}{|c|}{ Flexible ERR } & $\begin{array}{l}\text { Interme- } \\
\text { diate ERR }\end{array}$ & Rigid ERR \\
\hline Estonia & $\begin{array}{l}\text { 1992:06- } \\
\text { 2004:06 }\end{array}$ & & & & & & & $\begin{array}{l}\text { 2004:06- } \\
\text { 2011:01 }\end{array}$ & $\begin{array}{c}\text { since } \\
\text { 2011:01 }\end{array}$ \\
\hline Lithuania & $\begin{array}{l}\text { 1994:03- } \\
\text { 2004:06 }\end{array}$ & & & & & & & $\begin{array}{l}\text { 2004:06- } \\
\text { 2015:01 }\end{array}$ & $\begin{array}{c}\text { since } \\
\text { 2015:01 }\end{array}$ \\
\hline Latvia & & $\begin{array}{l}1994: 02- \\
2005: 04\end{array}$ & & & & & & $\begin{array}{l}\text { 2005:04- } \\
\text { 2014:01 }\end{array}$ & $\begin{array}{l}\text { since } \\
\text { 2014:01 }\end{array}$ \\
\hline Slovenia & & & & & & $\begin{array}{l}\text { 1994:01- } \\
\text { 2004:06 }\end{array}$ & & $\begin{array}{l}\text { 2004:06- } \\
\text { 2007:01 }\end{array}$ & $\begin{array}{c}\text { since } \\
\text { 2007:01 }\end{array}$ \\
\hline Poland & & & $\begin{array}{l}\text { 1990:01- } \\
1991: 10\end{array}$ & $\begin{array}{l}\text { 1991:10- } \\
\text { 1995:05 }\end{array}$ & $\begin{array}{l}1995: 05- \\
2000: 04\end{array}$ & & $\begin{array}{l}\text { since } \\
2000: 4\end{array}$ & & \\
\hline Czech R. & & $\begin{array}{l}\text { 1990:01- } \\
\text { 1996:02 }\end{array}$ & & & $\begin{array}{l}\text { 1996:02- } \\
\text { 1997:05 }\end{array}$ & $\begin{array}{c}\text { since } \\
\text { 1997:05 }\end{array}$ & & & \\
\hline Slovakia & & $\begin{array}{l}\text { 1990:01- } \\
\text { 1997:01 }\end{array}$ & & & $\begin{array}{l}\text { 1997:01- } \\
\text { 1998:10 }\end{array}$ & $\begin{array}{l}\text { 1998:10- } \\
\text { 2005:11 }\end{array}$ & & $\begin{array}{l}\text { 2005:11- } \\
\text { 2009:01 }\end{array}$ & $\begin{array}{c}\text { since } \\
\text { 2009:01 }\end{array}$ \\
\hline Hungary & & & & $\begin{array}{l}\text { 1994:01- } \\
\text { 2001:0 }\end{array}$ & $\begin{array}{l}\text { 2001:05- } \\
\text { 2008:02 }\end{array}$ & & $\begin{array}{c}\text { since } \\
\text { 2008:02 }\end{array}$ & & \\
\hline Bulgaria & $\begin{array}{c}\text { since } \\
\text { 1997:07 }\end{array}$ & & & & & $\begin{array}{l}\text { 1990:01- } \\
\text { 1997:07 }\end{array}$ & & & \\
\hline Romania & & & & & & od 1994:01 & & & \\
\hline Croatia & & & & $\begin{array}{c}\text { since } \\
\text { 1994:01 }\end{array}$ & & & & & \\
\hline
\end{tabular}


Table 2 The evolution of the monetary regimes in the emerging EU members in the period 1990-2018

\begin{tabular}{c|cccc}
\hline $\begin{array}{c}\text { Country/monetary } \\
\text { regime }\end{array}$ & $\begin{array}{c}\text { Monetary } \\
\text { nonautonomy }\end{array}$ & $\begin{array}{c}\text { Exchange-rate } \\
\text { targeting }\end{array}$ & $\begin{array}{c}\text { Inflation } \\
\text { targeting }\end{array}$ & Other anchors (targets) \\
\hline Estonia & since 2011:01 & $1992: 06-2011: 01$ & & \\
Lithuania & since 2015:01 & $1994: 03-2015: 01$ & & \\
Latvia & since 2014:01 & $1994: 02-2014: 01$ & & $1991: 10-2007: 01$ \\
Slovenia & since 2007:01 & & & monetary-based targeting \\
Poland & & $1990: 01-2000: 04$ & since 2000:04 & \\
Czech R. & & $1990: 01-1996: 02$ & since 1997:12 & 1998:10 \\
Slovakia & since 2009:01 & $1990: 01-1997: 01$ & & more targets \\
Hungary & & $1994: 01-2001: 05$ & since 2001:05 & $1991: 06-1997: 07$ \\
Bulgaria & & since 1997:07 & & $1994: 01-2005: 08$ \\
Romania & & & since 2005:08 & monetary-based targeting \\
Croatia & & since 1994:01 & \\
\hline
\end{tabular}

Source: Authors

and monetary flexibility, and who benefited from the role of the ER as a shock absorber in crisis circumstances. Therefore, the subject matter of this research study are the monetary policy frameworks or the monetary switches at the different stages of convergence towards the EZ. The aim of the research study is focused on the identification of the main challenges of the monetary authorities at different stages, as well as the efforts in choosing an adequate combination of the exchange rate and the monetary regimes in balancing between internal and external equilibria. Although the exchange rate regimes or monetary regimes were explored in the existing literature from the aspect of the emerging European economies, as well as the EZ per se, in this paper, the literature gap is filled with a sublimation of all the phases of monetary convergence from the beginning of transition, tracking the monetary evolution of emerging EU countries until the EZ participation (Table 1 and Table 2). The following hypotheses were tested in the paper: flexible exchange-rate regimes with the maintenance of monetary autonomy deliver more maneuver space for the monetary authorities by absorbing external shocks under crisis circumstances, and vice versa, rigid exchange-rate regimes, such as currency boards and the monetary union, are more vulnerable to macroeconomic overheating with consequent sharp internal and external adjustments in post-crisis periods. The hypotheses are tested by using the methods of induction, analysis, synthesis, descriptive statistical analysis, and the comparison method as well. The paper is structured as follows: Section 1 deals with the monetary frameworks and ERRs of emerging Europe at the first stage of monetary convergence. The crucial challenges of the second stage of monetary convergence, especially the ERM II participation, are highlighted in Section 2. In Section 3, the main difficulties of the emerging EU members at the third stage of functioning within the EZ are analyzed. The main concluding remarks are outlined in the final section.

\section{THE DIVERSITY OF MONETARY FRAMEWORKS AND ERRS BEFORE THE EU ENTRY}

The diversity is evident among the EEEs concerning the adoption of the ER and the monetary frameworks (Nerlich, 2002; Amerini, 2003; Frommel, 2006; International Monetary Fund, 2017). Most emerging economies used the ER as a nominal anchor or ER targeting in the macroeconomic stabilization phase. 
The reason for an almost uniform anti-inflationary recipe is well-known. The exchange rate represents a natural anchor in vulnerable economies, bearing in mind their (hyper)-inflationary past and persistent inflationary expectations. An exchange-rate peg is a transparent and clear anchor for market participants. Consequently, inflationary expectations could be anchored firmly and relatively quickly due to the confidence and credibility of the monetary authorities bound by the parity defense. Some countries kept different forms of the fixed ER, including the rigid form of the currency board, whereas other countries (strategically or in a crisis manner) switched the anchor towards the IT regime with a more flexible ER arrangement. In general, the three groups of countries could be identified according to the applied ER and monetary strategies.

The first monetary path assumes no change in the ER and the monetary regimes until joining the EU. This group includes Estonia, Lithuania and Latvia (the Baltic States). These countries used the ER as a nominal anchor (or ER targeting) in the macroeconomic stabilization phase, and even retained the same monetary strategy in the post-stabilization phase. According to the International Monetary Fund (2017), ER targeting comprises a currency board, a conventional fixed parity, an adjustable and crawling peg, all the way to a regime with wider fluctuation margins (corridors or target zones) on the flexibility continuum (Frenkel, 1999). Estonia and Lithuania have been using the currency board since June 1992 and March 1994, respectively. Latvia has been practicing a less rigid ER regime and a conventional fixed parity since February 1994. Estonia, Lithuania and Latvia have not changed the ERR even within the ERM II target zone at the second stage of monetary convergence towards the EZ. For more information about monetary evolution during the convergence process, we refer you to the cases of the Baltic States mentioned in Table 1 and Table 2.

The second monetary path includes the ER as a nominal anchor only at the beginning of transition in pursuing macroeconomic stabilization. The benefits related to the monetary strategy of ER targeting were decreasing over time, bearing in mind the inertia of inflation. At the same time, the costs were increasing, especially in connection with the real exchange rate appreciation and the worsening of the external imbalance. Poland, the Czech Republic, Slovakia and Hungary (Višegrad Group) abandoned the ER as a nominal anchor as a part of the strategic monetary shift. By implementing the exit strategy, these economies gradually raised the ER and monetary flexibility by accepting different intermediate ER arrangements (Josifidis, Allegret \& Beker Pucar, 2011; 2014). The monetary authorities of the Višegrad economies left ER targeting (the conventional fixed parity, the adjustable and crawling peg) and accepted intermediate ERRs, and finally managed/free floating in combination with the IT regime. After having accepted managed floating and an implicit IT monetary framework, the Slovak Republic experienced two relevant changes. Namely, after the EU accession, this economy participated in the ERM II mechanism, thus returning to the intermediate ER form. Since 2009, the second change has assumed a loss of the Slovakian monetary autonomy with its entry into the EZ. Poland, the Czech Republic and Hungary have not participated in the ERM II yet; currently, they are practicing the same combination of managed/free ER floating and the IT framework. Despite the common path from the ER as a nominal anchor to the IT policy, the pace of and the successfulness of the changes differed among the Višegrad economies. In order to learn about their monetary evolution in the period 1990-2018, we refer you to Table 1 and Table 2.

The third monetary path was followed by the former transition economies that had not accepted any of the previously mentioned monetary strategies (retained ER stability or rising ER flexibility). Instead of these paths, the countries belonging to this group accepted different hybrid regimes without an explicit and unique nominal anchor. This group includes Slovenia, Bulgaria, Romania and Croatia. Slovenia used different de jure regimes, having preferred more or less fixed regimes prior to the EU accession. After joining the EU in 2004, Slovenia approached the ERM II target zone so as to eventually become a member of the EZ in January 2007. Bulgaria, following the unsuccessful ER fixing initiated in 1991, switched 
towards free ER floating. Under the pressure of the currency crisis in 1997, the Bulgarian monetary authorities replaced managed ER floating and the nontransparent monetary strategy with the rigid ER arrangement of the currency board. Although the ER de facto had served as a nominal anchor since the beginning of transition, Bulgaria and Slovenia were forced to the de jure floating ERRs at the beginning of transition due to the insufficient level of the foreign exchange reserves necessary to maintain the parity (Nerlich, 2002). Croatia has been implementing a crawling peg as an intermediate regime and ER targeting since 1994, preserving the variations of these regimes prior to and after the EU accession in 2013. Romania had used different forms of intermediate ERRs without an explicit and transparent monetary strategy until 2004 and has been converging towards the managed floating ERR in combination with the IT regime since 2004 (Table 1 and Table 2).

It is not possible to determine a unique monetary strategy acceptable for all countries on the road to the EU. Although the common element of all the monetary strategies was the primary goal of the price stability, the other elements were specific and dependent on the applied ERR. A general success in anchoring inflationary expectations was independent of the applied monetary strategy or the nominal anchor. However, it is important that the chosen monetary strategy should reflect the price and, more broadly speaking, the macroeconomic stability necessary to underpin a further nominal and real convergence towards the EU and the EZ.

\section{THE SECOND STAGE OF MONETARY CONVERGENCE: A FOCUS ON THE ERM II TARGET ZONE}

Independently of the chosen monetary strategy on the road to the EU, member countries must pass through the second phase of monetary convergence on their way to the EZ membership. The accomplishment of the Maastricht criteria should guarantee the stability of the monetary union's single currency zone. One of the Maastricht criteria related to the ERR prior to the monetary union is known as the ERM II. Accessing the EU does not automatically involve participation in the ERM II. However, the decision to join the ERM II is crucial since an adequate level of nominal and real convergence with the rest of the EZ should precede this important step of monetary integration (Schadler, Drummond, Kuijs, Murgasova \& van Elkan, 2005). The more an economy is integrated and the more it has been converging with the rest of the EZ, the lesser the possibility for it to experience asymmetric external shocks, currency crises, and an inappropriate parity against the euro under the constrained monetary environment of the ERM II target zone. Since monetary autonomy is confined under the ERM II corridor, economies are trained for an even more rigid monetary environment of the monetary union with the total renouncement of monetary sovereignty (Bofinger, 2004; Schalder et al, 2005).

The ERM II represents the most flexible form of the hybrid (intermediate) ERR. It is the target zone or the corridor with the fluctuation margins of $+/-$ $15 \%$ around the fixed parity against the euro. The monetary framework of the ERM II is so designed to be flexible enough since the following ERRs are considered as acceptable (Stavárek, 2004, Backe \& Thimann, 2004):

- the conventional fixed parity against the euro as a classic fixed-parity without fluctuation margins;

- the narrow target zone or the wider target zone with fluctuation margins up to $+/-15 \%$ around the euro peg;

- the currency board.

On the other hand, the following ERRs are regarded as unacceptable:

- the fixed parity against other (non-euro) currencies;

- free ER floating;

- crawling pegs;

- unilateral euroization. 
Therefore, the elements that must be fulfilled in order to participate in the ERM II are:

- the central, fixed (not adjustable, crawling) parity;

- the parity defined to the euro;

- fluctuation margins of up to $+/-15 \%$.

At the second monetary stage, after the EU accession and prior to the EZ, there are two monetary paths possible to identify according to the applied ER and monetary regimes. The first assumes switching to the opposite side of the ER arrangements, i.e. from a flexible towards an intermediate form of the ERM II. In contrast to the ERR that will de facto be exposed to changes in accordance with the progress of monetary convergence, the monetary regime could be withheld in the IT form. Participation in the ERM II assumes the maintenance of the target zone in a period of two years, implying the targeting of both variables - the exchange rate and inflation - thus making a strict IT framework unacceptable. The simultaneous targeting of the ER and the inflation rate is very complicated under the ERM II framework. Numerous papers have explored the unsustainability aspect of the ERM II in attaining convergence criteria (Adahl, 2000; Begg, Eichengreen, Halpern, Hagen \& Wyplosz, 2003, Fahrholz, 2003; Eijffinger, 2003; Issing, 2003; Polanski, 2004; Stavarek, 2004). This complexity is the reason why to change the type of IT by accepting a dynamic approach from strict to flexible IT is preferable (Orlowski, 2005). Poland, the Czech Republic, Hungary and Romania follow this monetary path towards the EZ, while the Slovak Republic was on this track before its EZ 2009 entry.

Another monetary framework at the second stage of monetary convergence was practiced by the countries without a significant change in the monetary policy regime(ER targeting) and the ERR (the currency board or the conventional fixed parity against the euro). If the ERM II were a rigid mechanism (not relatively flexible as it is), these countries would experience the biggest change. In such a way, the countries with the fewest changes in the monetary policy, the ERR and the adjustment mechanisms at the second stage of monetary convergence are Estonia, Lithuania, Latvia, and Bulgaria. Bulgaria is still at the second stage of monetary convergence (and has been at this stage since 2007), whereas the Baltic countries are already at the third stage of the EZ participation (Estonia has been at this stage since 2011, Lithuania since 2014, and Latvia since 2015). Although the situation regarding the monetary strategy on the way to the EZ is less transparent in the case of Slovenia, this economy could be considered to have been following this monetary path without radical changes in the nominal anchor and the adjustment mechanisms. Now, Slovenia has been at the third stage since 2007, like the Baltic States.

The two-year participation in the ERM II, along with the fulfillment of the other Maastricht criteria, indicates that economic convergence is sustainable enough and that the economy is able to participate in the monetary union without significant asymmetries, imbalances and costly adjustments. The ERM II also provides information on the adequate central parity of the national currency in relation to the euro, which will become irrevocable by entering the EZ. However, the essential purpose of establishing the ERM II monetary arrangement prior to the EZ membership is a preparation for functioning within the monetary union. After entering the EZ, member countries cannot use the monetary policy and the ER policy countercyclically in order to isolate their national economies from external shocks. National monetary authorities can no longer favor the currency weakening in order to stimulate economic (export) activities and improve the external (deficit) position. The impact on the real economy and the external balance after entering the EZ can exclusively be made by budgetary and structural policies.

\section{THE THIRD STAGE OF MONETARY CONVERGENCE: THE MONETARY UNION}

\section{The Monetary Framework}

The decision to enter the ERM II is complex and crucial, and the same holds for the decision 
stipulating when to finalize monetary convergence and accept the euro. The exchange rate mechanism II can be an adequate framework for finalizing the convergence process, but it is necessary to select the right moment to leave the ERM II and accept a single currency. The moment of fundamental economic change always involves the analysis of the costs and benefits of both options, namely the ERM II vs the EMU (Ćorić \& Deskar Škrbić, 2017). A relatively wide corridor of $+/-15 \%$ in the ERM II provides sufficient monetary flexibility in order to correct the remaining differences in the real and the nominal indicators. On the other hand, the acceptance of the euro brings with itself lower interest rate premiums, lower real interest rates and a reduced risk of speculative attacks (Issing, 2003).

The benefits of a longer participation in the ERM II target zone can be preferable for some economies rather than their entering the monetary union. A longer participation involves the benefits of greater ER flexibility (the limited, but still present, role of the ER as a shock absorber) in adjusting the remaining differences in productivity, wage growth and inflation relative to the EZ. Once the euro is accepted, such differences will have to be neutralized by internal devaluation or an internal (restrictive) adjustment. The mentioned adjustment mechanism is painful since it includes the price, the wage, the output and employment lowering in order to restore competitiveness in a more difficult and painful way (De Grauwe \& Schnabl, 2004). The participation of the EU member states in the EZ will be decided in light of meeting the conditions necessary for accepting the single currency. The combination at the third stage of a monetary convergence is monetary nonautonomy and the monetary union as a rigid ERR. The choice of and a change in the ER and monetary regimes are no longer observed in the national context.

Two groups of countries are possible to identify at this stage of monetary convergence: the one with more radical and the other with smaller changes with respect to the nominal anchor. The first monetary path assumes the radical transformation of the monetary regime and a complete change in the nominal anchor in the sense of switching from the IT framework (with significant monetary flexibility) to the rigid ER regime of the monetary union (Belhocine, Crivelli, Geng, Scutaru, Wiegand \& Zhan, 2016). This group of countries passes through the strongest change in the ERR since, instead of the ERM II target zone (with significant fluctuation margins), they irrevocably fix the value of the domestic currency to the euro, further abolishing the national currency and the ER/monetary policy. This group includes Slovakia (which has been included in the group since 2009) and potentially includes Poland, the Czech Republic, Hungary and Romania since these EU members have not participated in the ERM II yet.

The second monetary path is followed by the economies with a less radical transformation of the monetary regime (International Monetary Fund, 2015; Bakker, 2017). It is a change from the ER as the nominal anchor of the monetary regime (with an inflexible monetary policy) towards a complete loss of monetary autonomy. The rigid ERR of the currency board and a conventional fixed parity are replaced with the rigid ERR of the monetary union. This change is weaker compared to the previous group of countries since a high level of rigidity is replaced with the highest level of rigidity or a complete loss of monetary sovereignty. Change in the adjustment mechanisms in the countries that targeted the ER from the start of the transition process is immeasurably weaker, bearing in mind the fact that these countries have not felt the advantages of a flexible monetary policy, having been accustomed to the deflationaryinflationary adjustment mechanism also prevailing in the EZ. Change is still formally large since the monetary policy is lost and there is no obligation to defend the parity. This monetary path has been followed by Slovenia, Estonia, Latvia and Lithuania, which have been the EZ members since 2007, 2011, 2014 , and 2015, respectively.

\section{Challenges for the Emerging EU Members under the Rigid Monetary Environment}

Whatever monetary framework towards the EZ has been chosen, functioning within the monetary union assumes an exclusive focus on a restrictive (or 
expenditure-reducing) external adjustment since the ER can no longer act as a shock absorber. The rigidity of such restrictive adjustment in the absence of a redistributive (expenditure-switching) adjustment was especially pronounced in the emerging EU members under crisis circumstances, namely under the Great 2008 Recession (Kang \& Shambaugh, 2014; Beker Pucar \& Srdić, 2018). Estonia, Lithuania and Latvia (the Baltic States) (the EZ members), on the one side, and Poland, the Czech Republic and Hungary (the EU members), on the other, could be regarded as the representatives of the two opposite monetary frameworks. As far as the mentioned economies are concerned, Figure 1 shows the inflation differential, whereas Figure 2 shows the productivity and GDP growth differentials compared to the EZ in the period 2000-2018. These figures reflect the internal imbalances on the monetary (Figure 1) and the real sides of the economy (Figure 2).

If we take a closer look into the two aspects of the internal balance, the monetary via the inflation rate, and the real via the GDP growth and productivity, Figure 1 and Figure 2 unambiguously demonstrate that the countries with a rigid ERR and ER targeting (the Baltic States) are more prone to macroeconomic overheating. Namely, inflation, the GDP growth and the productivity differences compared to the EZ in the pre-crisis period are more pronounced for the Baltic States compared to Poland, the Czech Republic, and Hungary. Consequently, as a reflection of internal overheating, the savings/investment gap (Figure 3, the left-hand side) culminated prior to the crisis, as well as the current account deficit (Figure 3, the righthand side).

All the macroeconomic imbalances, both the internal (Figure 1 and Figure 2) and the external (Figure 3), culminated prior to the Great 2008 Recession. Accordingly, the internal and external adjustments were the sharpest for the Baltic States in the postcrisis period, especially bearing in mind the fact that these economies were not able to use the ER as a shock absorber. Figure 4 expectedly shows higher nominal ER variations in the case of the floaters (the left-hand side) compared to the fixers (the righthand side). The only option for these economies was sharp internal devaluation (a restrictive, expenditurereducing adjustment) accompanied by a drop in the output and employment (as Figure 2 suggests) under the crisis-driven external shocks. On the contrary, on the road to the EZ, Poland, the Czech Republic and Hungary were able to use another, more convenient adjustment option of the currency weakening with a less bumpy road towards the EZ (Herrmann \& Jochem, 2013; Josifidis, Allegret \& Beker Pucar, 2014; Bakker, 2017). Figure 4 suggests that Poland mostly used the ER as a shock absorber with relatively the highest nominal exchange rate variations between the floaters. Alongside this fact, Poland was the only EEE not to experience a recession after the outbreak of the crisis. Due to the currency weakening under external shocks, Poland was able to avoid sharp internal devaluation. In the group of the fixers, Latvia experienced relatively higher nominal exchange rate corrections (mainly devaluation in the pre-crisis period), but that was the expected indicator since this economy had not formally accepted the currency board, as Estonia and Lithuania had.

As the case of the emerging EU members with a rigid ERR under the crisis impact clearly shows, the crucial sacrifice is the inability of the monetary countercyclical adjustment and a loss of the ER as a shock absorber under the crisis impact. The same pattern is present within the monetary union in the sense of lowered flexibility in adjusting to asymmetric shocks. The real exchange rate adjustment to such asymmetric shocks is completely performed through the price and wages, i.e. through internal devaluation (Gibson \& Palivos, 2013). The EZ 2010 crisis showed that it was not simple to perform these price adjustments without nominal ER adjustments, especially in the low-inflationary environment of the EZ. After the outbreak of the crisis in such a rigid environment, the internal balance deteriorated (unemployment rose, and the output fell) due to the stabilization of the external position. Taking into account the asymmetry within the EZ between the core and the periphery, the most severe consequences of the external adjustment were expectedly recorded in the vulnerable periphery countries. Being aware of the significant sacrifice of entering the EZ, Poland, Czech Republic and Hungary have not participated in 


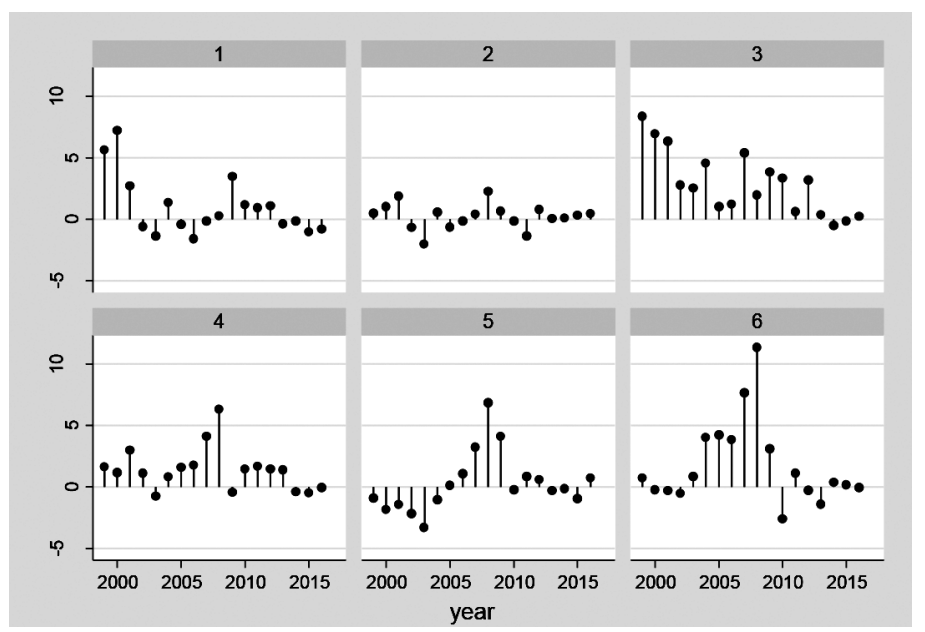

Notes: 1 - Poland, 2 - Czech Republic, 3 - Hungary, 4 - Estonia, 5 - Lithuania, 6 - Latvia. The inflation (the consumer prices, the annual percent) differential - the difference between the domestic inflation rate and the EZ inflation rate. The yearly time series of the national and the EZ inflation rates are obtained from the IMF International Financial Statistics and the WB World Development Indicators.

Figure 1 The inflation differential compared to the EZ for the selected emerging EU members in the period 20002018

Source: Authors
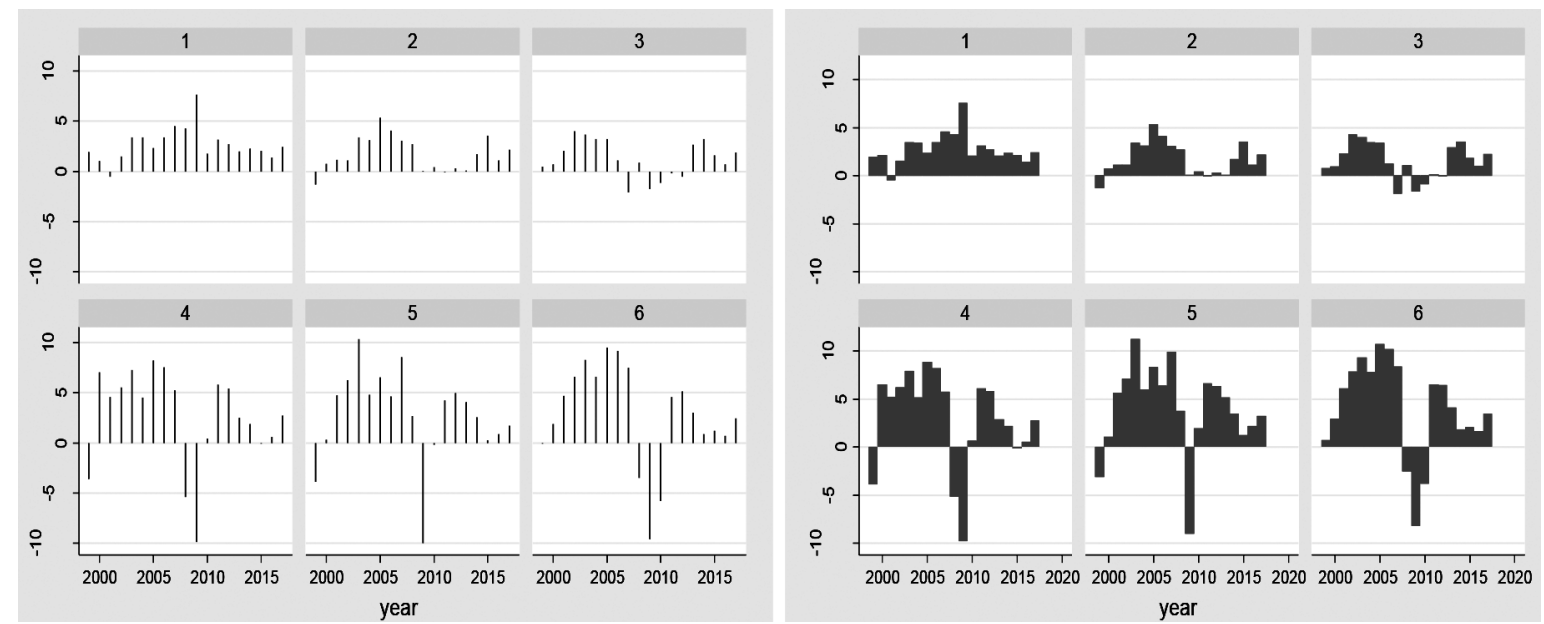

Notes: 1 - Poland, 2 - Czech Republic, 3 - Hungary, 4 - Estonia, 5 - Lithuania, 6 - Latvia. The GDP growth (the annual percent) difference - the difference between the national GDP growth and the EZ GDP growth. The productivity differential (GDP/employment) - the difference between the national variable and the EZ productivity variable. The yearly time series of the GDP growth, the GDP and employment, are obtained from the IMF International Financial Statistics and the WB World Development Indicators.

Figure 2 The GDP growth differential and the productivity differential compared to the EZ for the selected emerging EU members in the period 2000-2018 

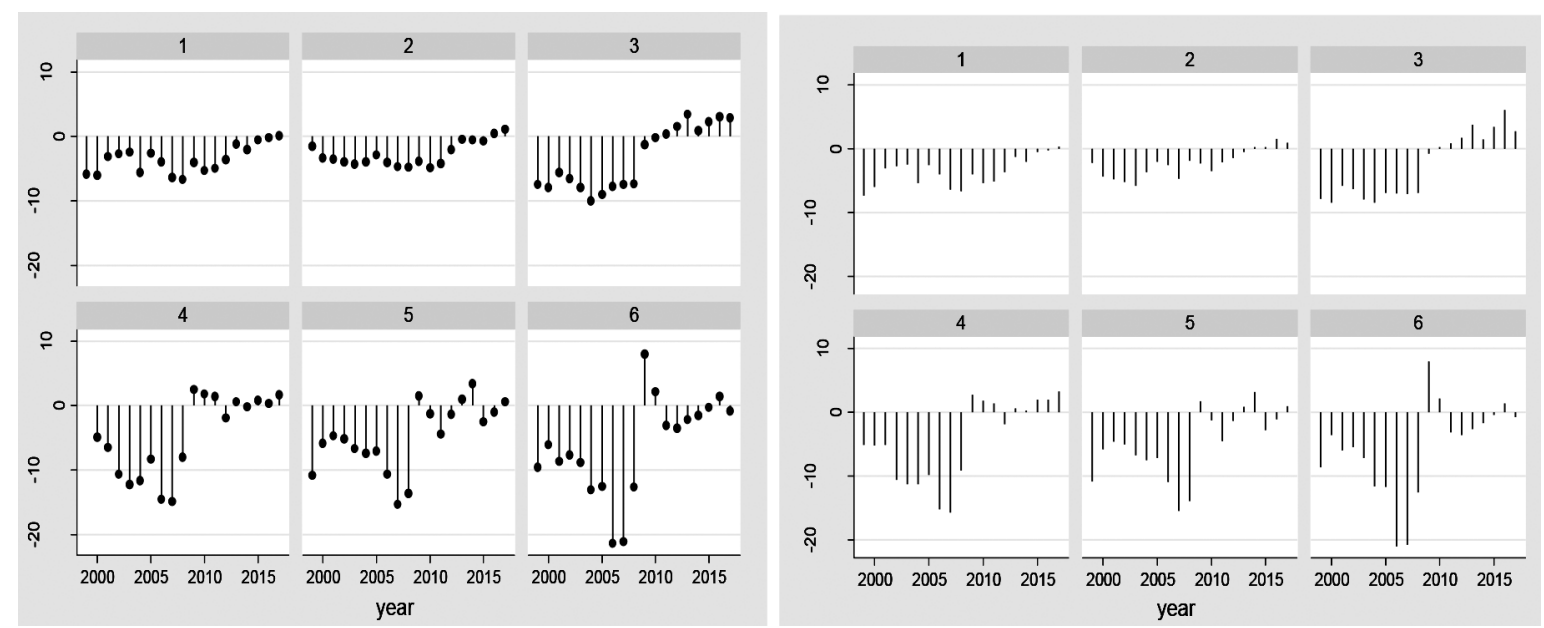

Notes: 1 - Poland, 2 - Czech Republic, 3 - Hungary, 4 - Estonia, 5 - Lithuania, 6 - Latvia. The yearly time series of the current account balance and the savings/investment gap are obtained from the IMF International Financial Statistics and the WB World Development Indicators.

Figure 3 The savings/investment gap and the external imbalance (the current account balance as a \% of the GDP) in the selected emerging EU members in the period 2000-2018

Source: Authors

NER changes, percentage

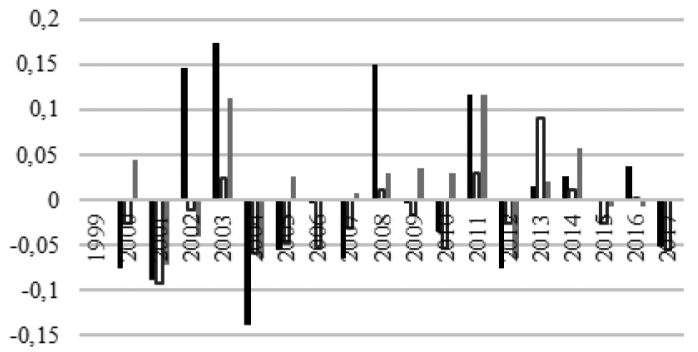

- POL $\square \mathrm{CZR}=\mathrm{HU}$
NER changes, percentage

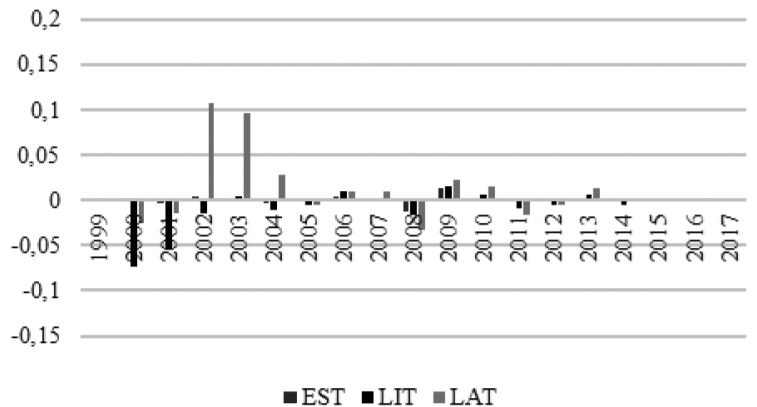

Napomena: POL - Poland, CZR - Czech Republic, HU - Hungary, EST - Estonia, LIT - Lithuania, LAT - Latvia. Yearly series of the nominal exchange rate (the domestic currency as per euro, the end of the period, the rate) obtained from the IMF International Financial Statistics.

Figure 4 The nominal exchange rate variations for the selected emerging EU fixers (on the right) and the floaters (on the left) in the period 1999-2017

Source: Authors 
the ERM II yet. Delayed participation is often viewed as the superior performance of these economies during the crisis compared to the other monetary frameworks (but also compared to the weaker EZ members), as well as the current weaknesses of the EZ itself (Palankai, 2015).

Given the fact that the monetary and the ER policies are sacrificed inside the monetary union, the countries should work out alternative adjustment mechanisms, labor mobility and the flexible labor market being one of them, which is stressed within the optimum currency area (OCA) theory (Mundell, 1961). Internal devaluation within the monetary union is inherently difficult, but the situation could even be worse due to the rigidness of the labor market as an obstacle to the internal devaluation mechanism (Wood, 2014). It prevents the functioning of market forces (rising unemployment) in lowering nominal wages. In addition to the aforementioned obstacles, even if the nominal wages are expected to fall in line with a reduction in employment, there is yet an obstacle in the relation between nominal wages the prices of domestic products. Due to insufficient competition on the commodity markets in certain deficit countries, the prices of domestic products do not fall simultaneously with nominal wages. More broadly speaking, the EZ was not created as an OCA. Labor is largely immobile for linguistic and cultural reasons, as well as for the personal and social costs of migration. The EU members are, however, open to trade, and capital is highly mobile. Even though the EZ may not have been created as an OCA ex ante, there are indications that it is moving in that direction ex post (Rose, 2008; Furrutter, 2012).

\section{CONCLUSION}

This paper highlights crucial challenges on the monetary path of the emerging EU members towards the euro zone (EZ). Progress towards the monetary union is observed through three stages, starting from the EU accession stage, via the pre-EZ stage, to ultimately the stage of the EZ participation at the end of monetary convergence. Emerging European
Economies (EEEs) adopted different monetary and ER strategies. However, there are two different monetary approaches that fundamentally can be identified. The one monetary framework assumes ER targeting as a monetary regime in which the ER serves as a nominal anchor, whereas the monetary policy is not autonomous. The other monetary framework combines inflation targeting (IT) with a flexible ER, where the ER serves as a shock absorber, whereas the monetary policy is free to act in a countercyclical manner. Independently of the initially implemented monetary framework, after the EU accession EEEs are, sooner or later, obliged to participate in the ERM II, the target zone in which monetary autonomy is significantly narrowed. The hypotheses were examined in the case of the two groups of countries. Poland, the Czech Republic and Hungary are the EU members at the second stage of monetary convergence that hesitate to enter the ERM II. Narrowed monetary flexibility is certainly the key reason since these economies performed better under a crisis impact. By analyzing the crucial macroeconomic indicators of the mentioned economies, it is confirmed that the floaters generally performed better, bearing in mind fewer internal and external imbalances in the situation where the ER serves as a buffer against external shocks. On the contrary, it is confirmed that the Baltic States, as an example of the emerging EU members which followed the opposite monetary path, experienced a deeper macroeconomic imbalance, as well as more profound internal and external adjustments in the post-crisis period. The monetary autonomy of these economies is otherwise limited since these are small and open economies where the benefits of the adoption of the euro prevail. On the other hand, Poland, the Czech Republic and Hungary (as well as the other EEEs that followed their monetary path towards the EU and the EZ) have much to lose in terms of monetary sovereignty, whereas inherent EZ weaknesses make the decision even more complicated. Therefore, the policy makers of the integration policies towards the EU and the EZ must bear in mind the significant economic sacrifice of a deeper monetary integration and the need for preparedness for functioning within the rigid monetary framework. Sustainable 
nominal and real convergence are the imperative of a deepening monetary integration with the EZ countries represents. Regardless of the common monetary framework at the third stage of monetary convergence, the external position and adjustment still depend on the individual macroeconomic performances of the EZ members and on the disciplined use of the remaining instruments of the economic policy as well. In spite of the identification of the general framework and the indications regarding the subject matter of the research study, future research should be directed towards the analysis of individual countries with respect to the choice of the exchange rate and monetary regimes at the considered stages of monetary convergence. Various econometric techniques ranging from the VAR and VEC models within the framework of timeseries analysis to nonstationary heterogeneous panels could be applied in order to further clarify the choices made by the economic policy makers of individual emerging EU members on the road towards the EZ.

\section{REFERENCES}

Adahl, M. (2000). Accession countries' choice of exchange rate system in preparation for EMU. Retrieved March 05, 2019, from http://www.riksbank.se/upload/Dokument_riksbank/ Kat_publicerat/Artiklar_PV/er00_4_artikel3.pdf

Amerini, G. (2003). Exchange rates in the candidate countries. Statistics in focus, Economy and finance, Theme (2) - 39. Retrieved March 05, 2019, from http://edz.bib.unimannheim.de/www-edz/pdf/statinf/03/KS-NJ-03-039-ENN-EN.pdf

Bakker, B. B. (2017, March). Exchange rate regimes in emerging Europe. Paper presented at the $5^{\text {th }}$ Regional Meeting of Governers, Umag.

Backe, P., \& Thimann, C. (2004). The acceding countries' strategies towards ERM II and the adoption of the Euro: An analytical review. ECB Occasional Paper 10.

Beker Pucar, E., \& Srdić, S. (2018). Vulnerability of emerging Europe in external adjustment and financing mechanisms. RECEO, 49(3), 93-121.
Belhocine, N., Crivelli, E., Geng, N., Scutaru, T., Wiegand, J., \& Zhan, Z. (2016). Taking stock of monetary and exchange rate regimes in emerging Europe. IMF European department paper.

Begg, D., Eichengreen, B., Halpern, L., Hagen, J., \& Wyplosz, C. (2003). Sustainable regimes of capital movements in accession countries. CEPR Policy Paper 10.

Bofinger, P. (2004). Exchange rate policies and institutional arrangements in the transition process to European Monetary Union. EUI Working Paper RSCAS 2004/17.

Ćorić, T., \& Deskar-Škrbić, M. (2017). Croatian path towards the ERM2: why, when and what can we learn from our peers? Ekonomski pregled, 68(6), 611-637.

De Grauwe, P., \& Schnabl, G. (2004). Exchange rate regimes and macroeconomic stability in Central and Eastern Europe. CESifo Working Paper 1182.

Eijffinger, S. C. W. (2003). Accession countries and ERM II. Briefing paper on "The conduct of monetary policy and an evaluation of the economic situation in Europe - 3rd quarter 2003 (August 2003)" for the European Parliament. Retrieved March 05, 2019, from http://www.europarl. europa.eu/comparl/econ/pdf/emu/speeches/20030910/ eijffinger.pdf

European Commission. (1998). Composite paper 1998. Retrieved March 05, 2019, from http://ec.europa.eu/enlargement/ archives/pdf/key_documents/1998/composite_en.pdf

Fahrholz, C. (2003). Strategic exchange-rate policy of accession countries in ERM II. Ezoneplus Working Paper 14. Retrieved March 05, 2019, from http://www.ezoneplus.org/archiv/ ezoneplus_wp_fourteen.pdf

Frenkel, J. A. (1999). No single currency regime is right for all countries and at all times. NBER Working Paper 7338.

Frommel, M. (2006). Volatility regimes in Central and Eastern European countries' exchange rates. Hannover Economic Papers (HEP) dp-333, Leibniz Universität Hannover, Wirtschaftswissenschaftliche Fakultät.

Furrutter, M. (2012). The Eurozone: The optimal currency area? IFIER papers 02/2012.

Gibson, H. D., \& Palivos, T. (2013). The crisis in the euro-area: An analytic overview. Special Conference Paper 28. 
Herrmann, S., \& Jochem, A. (2013). Current account adjustment in EU countries: Does Euro-area membership make a difference? Discussion Paper 49/2013, Deutsche Bundesbank.

International Monetary Fund. (2015). Central and Eastern Europe: New member states (NMS) policy forum - Selected issues. Retrieved March 05, 2019, from http://www.imf.org/ external/pubs/ft/scr/2015/cr1598.pdf

International Monetary Fund. (2017). Annual report on exchange arrangements and exchange restrictions. Retrieved March 05, 2019, from https://www.imf.org/en/Publications/ Annual-Report-on-Exchange-Arrangements-and-ExchangeRestrictions/Issues/2018/08/10/Annual-Report-on-ExchangeArrangements-and-Exchange-Restrictions-2017-44930

Mundell, R. A. (1961). A Theory of optimum currency areas. The American Economic Review, 51(4), 657-665.

Issing, O. (2003). Considerations on monetary policy strategies for accession countries. Retrieved March 05, 2019, from http:// www.ecb.int/press/key/date/2003/html/sp030228.en.html

Josifidis, K., Allegret, J-P., \& Beker Pucar, E. (2011). Inflation targeting and exchange rate regimes in Serbia and selected transition economies. Eastern European Economics, 49(4), 88105. doi.org/10.2753/EEE0012-8775490405

Josifidis, K., Allegret, J-P., \& Beker Pucar, E. (2014). Adjustment mechanisms and exchange rate regimes in 2004 new EU members during the financial crisis. Post-Communist Economies, 25(1), 1-17. doi.org/10.1080/14631377.2013.756614

Kang, J-S., \& Shambaugh, J-C. (2014). Progress towards external adjustment in the euro area periphery and the Baltics. Working Paper 14/131, International Monetary Fund.
Nerlich, C. (2002, April). Exchange rate strategies of EU accession countries: Does exchange rate policy matter? Paper presented at the KOBE Research Seminar on Regional economic, financial and monetary co-operation: the European and Asian experience, Frankfurt.

Orlowski, L. T. (2005). Monetary policy adjustments on the final passage towards the euro. Center for Social and Economic Research, Warsaw. Retrieved March 05, 2019, from http:// www.case-research.eu/upload/publikacja_plik/4830919_ sa294ok.pdf

Palankai, T. (2015). The introduction of the euro and Central Europe. Economics and Sociology, 8(2), 51-69. doi:10.14254/2071- 789X.2015/8-2/5

Polanski, Z. (2004). Poland and the Euro zone enlargement: Monetary policy, ERM II, and other issues. Retrieved March 05, 2019, from http://www.defi-univ.org/IMG/pdf/23.pdf

Rose, A. K. (2008). Is EMU becoming an optimum currency area? The evidence on trade and business cycle synchronization. Retrieved March 05, 2019, from http://faculty.haas.berkeley. edu/arose/emumetaecb.pdf

Stavarek, D. (2004). ERM II: Potential source of instability in the new EU-member countries. Retrieved March 05, 2019, from http://www-1.mtk.ut.ee/varska/2004/2_Rahapol_Finturud/ Stavarek.pdf

Schadler, S., Drummond, P., Kuijs, L., Murgasova, Z., \& van Elkan, R. (2005). Adopting the Euro in Central Europe Challenges of the next step in european integration. IMF Occasional Paper 234.

Wood, R. (2014). Eurozone macroeconomic framework: Reducing internal and external imbalances. MPRA Paper 53569 .
Received on $6^{\text {th }}$ March 2019, after revision, accepted for publication on $17^{\text {th }}$ April 2019 Published online on $25^{\text {th }}$ April 2019 
Emilija Beker Pucar is an associate professor at the Faculty of Economics in Subotica, University of Novi Sad where she obtained her PhD thesis in the scientific field of General Economic Theory and Policy. She teaches International Economics, International Finance, Macrometrics and International Macroeconomics at the bachelor, master and doctoral academic levels. The key area of her research interest are economic policies, with a special focus on the monetary policy and exchangerate regimes.

Olgica Glavaski is an assistant professor at Faculty of Economics in Subotica, University of Novi Sad. She obtained her PhD thesis at the Faculty of Economics in Belgrade in the scientific field of Economics. She teaches Macroeconomics of the EU, Economics of the Public Sector, Macrometrics, Political Economy of European Integration at the bachelor, master and doctoral academic levels. The key area of her research interest are economic policies, with a special focus on the fiscal policy and the sustainability of public spending. 


\title{
MONETARNE FAZE I OKVIRI EMERGENTNIH ZEMALJA EVROPSKE UNIJE
}

\author{
Emilija Beker Pucar* i Olgica Glavaški \\ Ekonomski fakultet u Subotici, Univerzitet u Novom Sadu
}

U radu se razmatraju monetarne faze i okviri emergentnih zemalja Evropske unije (EU) na putu ka evro zoni (EZ). U prvoj fazi pre pristupanja EU, identifikovana su tri monetarna okvira, dok su u drugoj fazi pre pristupanja EZ, emergentne EU zemlje kombinovale targetiranje kursa sa rigidnim/fiksnim režimima deviznog kursa, s jedne strane, i inflaciono targetiranje (IT) sa Evropskim mehanizmom deviznog kursa (Exchange Rate Mechanism - ERM II), s druge strane. Poslednja faza monetarne konvergencije podrazumeva monetarnu ne-autonomiju unutar monetarne unije kao rigidnog režima kursa, pri čemu se devizni kurs i monetarne politike žrtvuju kao anticiklični instrumenti. Zemlje sa rigidnim režimima su podložnije makroekonomskom pregrejavanju, beležeći lošije makroekonomske performanse u poređenju sa zemljama fluktuirajućeg kursa. Teškoće pri održavanju stabilnosti unutar rigidnog monetarnog okruženja, kao što je monetarna unija, kao i inherentne slabosti EZ, krucijalni su motivi odlaganja pojedinih zemalja EU pristupanju ERM II target zoni.

Ključne reči: evro zona, Evropski mehanizam deviznog kursa, monetarna konvergencija, mehanizmi prilagođavanja, monetarni i režimi deviznog kursa

JEL Classification: E52, F15, F45

\section{UVOD}

Emergentne zemlje (zemlje u razvoju i usponu) Evropske unije (EU) ne prihvataju automatski evro nakon njenom pristupanja, iako participiraju u Ekonomskoj i monetarnoj uniji (EMU). EMU podrazumeva postepeni razvojni proces zemalja kandidata (proces konvergencije), koji na kraju puta

* Korespondencija: E. Beker Pucar, Ekonomski fakultet u Subotici, Univerzitet u Novom Sadu, ul. dr Sime Miloševića 16, 21000 Novi Sad, Republika Srbija; e-mail: emilijab@ef.uns.ac.rs dovodi do prihvatanja zajedničke valute. Imajući u vidu da sve emergentne zemlje EU, pre ili kasnije, moraju prihvatiti evro, monetarne vlasti emergentne Evrope su suočene sa neophodnim promenama režima deviznog kursa i monetarnih režima. U suštini, tri ključne faze mogu se identifikovati u procesu monetarne konvergencije ka evro zoni (European Commission, 1998; De Grauwe \& Schnabl, 2004). Prva faza uključuje period do pristupanja EU, druga faza period između pristupanja EU i prihvatanja evra, dok treća faza podrazumeva funkcionisanje unutar evro zone (EZ). 
Emergentne evropske ekonomije (EEE) su birale različite strategije deviznog kursa i monetarne politike na putu ka EU. S jedne strane, zemlje su se odlučivale za paritet u različitim formama: valutni odbor, konvencionalni paritet, središnji (hibridni) aranžmani (fiksni režimi). Monetarne vlasti fiksnih režima su prihvatale targetiranje kursa kao monetarni okvir sa ograničenim manevarskim prostorom. Kao drugu soluciju, monetarne vlasti su odabrale upravljano fluktuirajući kurs i inflaciono targetiranje (IT) (fleksibilni režimi). Pomenuta monetarna strategija podrazumeva fleksibilniju monetarnu politiku, s obzirom da nije ograničena determinisanim evroparitetom. Dok prva faza monetarne konvergencije pruža autonomiju u odabiru adekvatne monetarne opcije, druga faza je ograničavajuća jer, pre ili kasnije, EU članice moraju ispuniti kriterijume konvergencije iz Mastrihta, uključujući i Evropski mehanizam deviznog kursa (Exchange Rate Mechanism - ERM II) target zonu. Druga faza monetarne konvergencije predstavlja pravi izazov za monetarne vlasti EEE, jer je veoma teško uskladiti nominalnu i realnu konvergenciju unutar ERM II target zone. Evolucija režima deviznog kursa i monetarne politike emergentnih zemalja EU, na putu ka EZ u periodu 1990-2018, prikazana je u Tabeli 1 i Tabeli 2.

Održiva realna i nominalna konvergencija EEE je preduslov stabilnog funkcionisanja unutar ograničenog monetarnog okruženja ERM II. ERM II target zona je priprema za još rigidniji monetarni ambijent unutar EZ, imajući u vidu potpuni gubitak monetarne autonomije. Pomenuti monetarni prelazi su kompleksni, posebno za zemlje sa fluktuirajućim režimima. Ove zemlje su naviknute na veću fleksibilnost deviznog kursa i monetarne politike, pri čemu je korist od deviznog kursa, kao apsorbera šokova u kriznim okolnostima, bila evidentna.

Tabela 1 Evolucija režima deviznog kursa emergentnih zemalja EU, u periodu 1990-2018.

\begin{tabular}{|c|c|c|c|c|c|c|c|c|c|}
\hline $\begin{array}{l}\text { Zemlja/ } \\
\text { režim kursa }\end{array}$ & $\begin{array}{l}\text { Valutni } \\
\text { odbor }\end{array}$ & $\begin{array}{c}\text { Konvenci- } \\
\text { onalno fiksni } \\
\text { kurs }\end{array}$ & $\begin{array}{c}\text { Prilagodljivi } \\
\text { paritet }\end{array}$ & $\begin{array}{l}\text { Pokretni } \\
\text { paritet }\end{array}$ & $\begin{array}{c}\text { Pokretni } \\
\text { koridor ili } \\
\text { target zona }\end{array}$ & $\begin{array}{l}\text { Upravljano } \\
\text { fluktuiranje }\end{array}$ & $\begin{array}{l}\text { Slobodno } \\
\text { fluktuiranje }\end{array}$ & $\begin{array}{c}\text { Target zona } \\
\text { ERM II }\end{array}$ & $\begin{array}{c}\text { Monetarna } \\
\text { unija } \\
\text { (EZ) } \\
\end{array}$ \\
\hline & $\begin{array}{l}\text { Rigidni } \\
\text { režim }\end{array}$ & & \multicolumn{3}{|c|}{ Središnji (hibridni) režim } & \multicolumn{2}{|c|}{ Fleksibilni režim } & $\begin{array}{l}\text { Središnji } \\
\text { režim }\end{array}$ & $\begin{array}{l}\text { Rigidni } \\
\text { režim }\end{array}$ \\
\hline Estonija & $\begin{array}{l}\text { 1992:06- } \\
\text { 2004:06 }\end{array}$ & & & & & & & $\begin{array}{c}\text { 2004:06- } \\
\text { 2011:01 }\end{array}$ & od 2011:01 \\
\hline Litvanija & $\begin{array}{l}1994: 03- \\
2004: 06\end{array}$ & & & & & & & $\begin{array}{c}\text { 2004:06- } \\
\text { 2015:01 }\end{array}$ & od 2015:01 \\
\hline Letonija & & $\begin{array}{l}1994: 02- \\
2005: 04\end{array}$ & & & & & & $\begin{array}{c}2005: 04- \\
2014: 01\end{array}$ & od 2014:01 \\
\hline Slovenija & & & & & & $\begin{array}{l}\text { 1994:01- } \\
\text { 2004:06 }\end{array}$ & & $\begin{array}{c}\text { 2004:06- } \\
\text { 2007:01 }\end{array}$ & od 2007:01 \\
\hline Poljska & & & $\begin{array}{l}\text { 1990:01- } \\
\text { 1991:10 }\end{array}$ & $\begin{array}{l}\text { 1991:10- } \\
\text { 1995:05 }\end{array}$ & $\begin{array}{l}\text { 1995:05- } \\
\text { 2000:04 }\end{array}$ & & od 2000:4 & & \\
\hline Češka R. & & $\begin{array}{l}\text { 1990:01- } \\
\text { 1996:02 }\end{array}$ & & & $\begin{array}{l}1996: 02- \\
1997: 05\end{array}$ & od 1997:05 & & & \\
\hline Slovačka & & $\begin{array}{l}\text { 1990:01- } \\
\text { 1997:01 }\end{array}$ & & & $\begin{array}{l}\text { 1997:01- } \\
\text { 1998:10 }\end{array}$ & $\begin{array}{l}\text { 1998:10- } \\
\text { 2005:11 }\end{array}$ & & $\begin{array}{l}\text { 2005:11- } \\
\text { 2009:01 }\end{array}$ & od 2009:01 \\
\hline Mađarska & & & & $\begin{array}{l}\text { 1994:01- } \\
\text { 2001:0 }\end{array}$ & $\begin{array}{l}\text { 2001:05- } \\
2008: 02\end{array}$ & & od 2008:02 & & \\
\hline Bugarska & od 1997:07 & & & & & $\begin{array}{l}\text { 1990:01- } \\
\text { 1997:07 }\end{array}$ & & & \\
\hline Rumunija & & & & & & od 1994:01 & & & \\
\hline Hrvatska & & & & od 1994:01 & & & & & \\
\hline
\end{tabular}

Izvor: Autori 
Tabela 2 Evolucija monetarnih režima emergentnih zemalja EU, u periodu 1990-2018.

\begin{tabular}{|c|c|c|c|c|}
\hline $\begin{array}{l}\text { Zemlja/monetarni } \\
\text { režim }\end{array}$ & $\begin{array}{c}\text { Monetarna ne- } \\
\text { autonomija }\end{array}$ & $\begin{array}{c}\text { Targetiranje deviznog } \\
\text { kursa }\end{array}$ & $\begin{array}{l}\text { Inflaciono } \\
\text { targetiranje }\end{array}$ & $\begin{array}{c}\text { Ostala nominalna sidra } \\
\text { (targeti) }\end{array}$ \\
\hline Estonija & od 2011:01 & 1992:06-2011:01 & & \\
\hline Litvanija & od 2015:01 & $1994: 03-2015: 01$ & & \\
\hline Letonija & od 2014:01 & 1994:02-2014:01 & & \\
\hline Slovenija & od 2007:01 & & & $\begin{array}{l}\text { 1991:10-2007:01 } \\
\text { Targetiranje mon. agregata }\end{array}$ \\
\hline Poljska & & 1990:01-2000:04 & od 2000:04 & \\
\hline Češka R. & & 1990:01-1996:02 & od 1997:12 & \\
\hline Slovačka & od 2009:01 & 1990:01-1997:01 & & $\begin{array}{l}\text { 1998:10 } \\
\text { Više targeta }\end{array}$ \\
\hline Mađarska & & 1994:01-2001:05 & od 2001:05 & \\
\hline Bugarska & & od 1997:07 & & 1991:06-1997:07 \\
\hline Rumunija & & & od 2005:08 & $\begin{array}{l}\text { 1994:01-2005:08 } \\
\text { Targetiranje mon. agregata }\end{array}$ \\
\hline Hrvatska & & od 1994:01 & & \\
\hline
\end{tabular}

Izvor: Autori

Predmet istraživanja $\mathrm{u}$ radu predstavljaju okviri monetarne politike ili monetarni prelazi u različitim fazama konvergencije ka EZ.

Cilj istraživanja usmeren je ka identifikaciji glavnih izazova monetarnih vlasti $u$ različitim fazama monetarne konvergencije, kao i napora pri odabiru adekvatne kombinacije režima deviznog kursa i monetarne politike, pri balansiranju između interne i eksterne ravnoteže. Iako se u literaturi preispituju režimi deviznog kursa, ili režimi monetarne politike sa aspekta emergentnih evropskih ekonomija, kao i funkcionisanje EZ per se, u ovom radu se jaz u literaturi popunjava sublimiranjem svih faza monetarne konvergencije od početka tranzicije, praćenjem monetarne evolucije emergentnih zemalja EU sve do participacije u EZ (Tabele 1 i 2).

$\mathrm{U}$ radu se testira hipoteza da fleksibilni režimi deviznog kursa, uz zadržavanje monetarne autonomije, pružaju veći manevarski prostor monetarnim vlastima, apsorbujući eksterne šokove u kriznim okolnostima. I obrnuto, rigidni režimi deviznog kursa, poput valutnog odbora i monetarne unije, podložniji su makroekonomskom pregrejavanju, sa posledičnim oštrijim internim i eksternim prilagođavanjima u post-kriznom periodu.
Hipoteze se testiraju primenom metoda indukcije, analize, sinteze, deskriptivne statističke analize, kao i metoda komparacije.

Rad je strukturiran na sledeći način: u prvom delu se analiziraju monetarni i režimi deviznog kursa emergentne Evrope $\mathrm{u}$ prvoj fazi monetarne konvergencije; krucijalni izazovi druge faze monetarne konvergencije, posebno participacija $u$ ERM II, naglašeni su u drugom delu rada; u trećem delu su istaknute ključne teškoće emergentnih zemalja EU u trećoj fazi funkcionisanja unutar EZ; zaključna razmatranja su sumirana u poslednjem delu rada.

\section{DIVERZITET MONETARNIH I REŽIMA DEVIZNOG KURSA PRE PRISTUPANJA EVROPSKOJ UNIJI}

Između EEE je prisutan diverzitet po pitanju prihvatanja režima deviznog kursa i monetarnog okvira (Nerlich, 2002; Amerini, 2003; Frommel, 2006, International Monetary Fund, 2017). Većina emergentnih ekonomija primenjuje devizni kurs kao nominalno sidro ili targetiranje kursa $u$ fazi makroekonomske stabilizacije. Razlog gotovo 
uniformnog anti-inflatornog recepta je dobro poznat. Devizni kurs predstavlja prirodno sidro u ranjivim ekonomijama, imajući u vidu njihovu (hiper)inflatornu prošlost i perzistentna infatorna očekivanja. Paritet deviznog kursa je transparentno i jasno sidro za tržišne učesnike. Posledično, inflatorna očekivanja mogu biti čvrsto i relativno brzo usidrena zahvaljujući poverenju i kredibilitetu monetarnih vlasti obavezanih odbranom postavljenog pariteta. Zemlje su primenjivale različite forme fiksnog kursa, uključujući i rigidnu formu valutnog odbora, dok su druge zemlje (strateški ili u kriznim okolnostima), menjale sidro ka režimu IT sa fleksibilnijim aranžmanima. Generalno, tri grupe zemalja se mogu identifikovati prema primenjenim strategijama kursa i monetarne politike.

Prva monetarna putanja ne pretpostavlja promene režima deviznog kursa i monetarne politike do pridruživanja EU. Ovoj grupi pripadaju Estonija, Litvanija i Letonija (Baltičke zemlje). Pomenute zemlje su upotrebile kurs kao nominalno sidro u fazi makroekonomske stabilizacije, ali su i u post-stabilizacionoj fazi zadržale isti monetarni okvir. Prema International Monetary Fund-u (2017), targetiranje kursa obuhvata valutni odbor, konvencionalni fiksni paritet, prilagodljivi i pokretni paritet, sve do režima sa širim marginama fluktuacije (koridori ili target zone) u kontinuumu fleksibilnosti (Frenkel, 1999). Estonija i Litvanija su prihvatile valutni odbor od 1992. i 1994. respektivno. Letonija je praktikovala manje rigidan kurs, odnosno, konvencionalni fiksni paritet od 1994. Estonija, Litvanija i Letonija nisu menjale režim kursa čak i unutar ERM II target zone u drugoj fazi monetarne konvergencije ka EZ (Tabela 1 i Tabela 2).

Druga monetarna putanja uključuje kurs kao nominalno sidro samo na početku tranzicije, pri postizanju makroekonomske stabilnosti. Koristi povezane sa monetarnom strategijom targetiranja kursa su se smanjivale tokom vremena usled inflacione inertnosti. $U$ isto vreme, troškovi su se povećavali, a posebno u vezi sa apresijacijom realnog deviznog kursa i pogoršanjem eksterne neravnoteže. Poljska, Češka Republika, Slovačka i Mađarska (Višegradska grupa), napustile su kurs kao nominalno sidro u sklopu strateškog monetarnog prelaza. Sprovodeći izlaznu strategiju, pomenute ekonomije postepeno povećavaju fleksibilnost kursa i monetarne politike, prihvatajući različite središnje aranžmane kursa (Josifidis, Allegret \& Beker Pucar, 2011). Monetarne vlasti Višegradskih ekonomija napuštaju targetiranje kursa (konvencionalni, prilagodljivi i pokretni paritet) i prihvataju središnje aranžmane i, konačno, upravljano/slobodno fluktuiranje $u$ kombinaciji sa IT. Nakon prelaska na upravljano fluktuiranje i implicitno IT, Slovačka je iskusila dve relevantne promene. Naime, nakon pristupanja EU, ova ekonomija je učestvovala u ERM II mehanizmu vraćajući se na središnje devizne aranžmane. Druga promena usledila je 2009, gubitkom slovačkog monetarnog suvereniteta pristupanjem EZ. Poljska, Češka Republika i Mađarska još uvek nisu pristupile ERM II, trenutno praktikujući kombinaciju upravljanog/slobodnog fluktuiranja sa IT okvirom (Tabela 1 i Tabela 2). Uprkos zajedničkoj monetarnoj putanji od deviznog kusa kao nominalnog sidra ka politici IT, dinamika i uspešnost promena razlikovali su se između Višegradskih zemalja.

Treća monetarna putanja praćena je od strane nekadašnjih tranzicionih ekonomija, koje nisu prihvatile ni jednu od prethodno pomenutih strategija (zadržanu stabilnost ili povećanu fleksibilnost kursa). Umesto identifikovanih putanji, posmatrana grupa zemalja je prihvatala različite hibridne režime, bez eksplicitnog i jedinstvenog nominalnog sidra. Slovenija, Bugarska, Rumunija i Hrvatska su pratile pomenutu putanju. Slovenija je primenila različite de jure režime, preferirajući, više ili manje, fiksne režime pre pristupanja EU. Nakon pristupanja EU 2004, Slovenija se priključila ERM II target zoni do ulaska u EZ januara 2007. Nakon neuspešnog fiksiranja bugarske valute 1991, monetarne vlasti prihvataju fleksibilan kurs. Međutim, pod pritiskom valutne krize 1997, u Bugarskoj se režim upravljanog fluktuiranja i ne-transparentne monetarne strategije zamenjuje rigidnim deviznim aranžmanom valutnog odbora. Iako je kurs de facto služio kao nominalno sidro od početka tranzicije, Bugarska i Slovenija su najpre bile prisiljene na de jure fluktuirajuće aranžmane, usled nedovoljnog nivoa deviznih rezervi neophodnih za održavanje pariteta (Nerlich, 
2002). U Hrvatskoj je implementiran pokretni paritet, kao središnji režim i targetiranje kursa od 1994, uz varijacije ovih režima pre i nakon pristupanja EU 2013. U Rumuniji su se primenjivale različite forme središnjih režima, bez eksplicitne i transparentne monetarne strategije do 2004, nakon čega se prihvata režim upravljanog fluktuiranja u kombinaciji sa IT (Tabela 1 i Tabela 2).

Nije moguće precizirati jedinstvenu monetarnu strategiju, prihvatljivu za sve zemlje na putu ka EU. Iako je zajednički element svih monetarnih strategija primarni cilj cenovne stabilnosti, drugi elementi su specifični i zavisni od primenjenog režima kursa. Međutim, važno je da izabrana monetarna strategija reflektuje cenovnu i, šire posmatrano, makroekonomsku stabilnost neophodnu kao potpora dalje nominalne i realne konvergencije ka EU i EZ.

\section{DRUGA FAZA MONETARNE KONVERGENCIJE: FOKUS NA ERM II TARGET ZONU}

Nezavisno od odabrane monetarne strategije na putu ka EU, zemlje članice moraju proći kroz drugu fazu monetarne konvergencije na putu ka EZ. Ispunjavanje kriterijuma iz Mastrihta bi trebalo da garantuje stabilnost jedinstvene valutne zone. Jedan od Mastrihtskih kriterijuma je u vezi sa primenjenim režimom kursa pre pristupanja monetarnoj uniji, poznat kao ERM II. Pristupanje EU ne znači i automatsko priključivanje ERM II. Međutim, odluka u vezi sa priključenjem ERM II je krucijalna, s obzirom da bi adekvatni nivo nominalne i realne konvergencije sa ostatkom EZ trebalo da prethodi ovom važnom koraku monetarne integracije. Što je data ekonomija integrisanija i što više konvergira ostatku EZ, manja je mogućnost prelivanja asimetričnih eksternih šokova, valutnih kriza, kao i neodgovarajućeg evro-pariteta, pod limitirajućim monetarnim okruženjem ERM II. Imajući u vidu da je monetarna autonomija ograničena unutar ERM II koridora, ekonomije se pripremaju za još rigidnije okruženje monetarne unije, uz potpuno odricanje od monetarnog suvereniteta (Bofinger, 2004;
Schadler, Drummond, Kuijs, Murgasova \& van Elkan, 2005).

ERM II predstavlja najfleksibilniju formu hibridnog (središnjeg) režima kursa. U pitanju je target zona, ili koridor sa marginama fluktuacije $+/-15 \%$ oko centralnog evro-pariteta. Monetarni okvir ERM II je dizajniran da bude dovoljno fleksibilan, jer se sledeći režimi smatraju prihvatljivim (Stavarek, 2004, Backe \& Thimann, 2004):

- konvencionalno fiksni paritet $\mathrm{u}$ odnosu na evro kao klasičan fiksni paritet bez margina fluktuacije;

- uža target zona ili šira target zona sa marginama do +/-15\% oko evro-pariteta;

- valutni odbor.

Sa druge strane, sledeći režimi kursa se smatraju neprihvatljivim:

- fiksni paritet definisan u odnosu na druge valute (izuzev evra);

- slobodno fluktuirajući kurs;

- pokretni paritet;

- unilateralna evroizacija.

Prema tome, elementi koji moraju biti ispunjeni za učestvovanje u ERM II su:

- centralni, fiksni (ne prilagodljivi, pokretni) paritet;

- paritet definisan u odnosu na evro;

- margine fluktuacije do $+/-15 \%$.

U drugoj fazi monetarne konvergencije, dve monetarne putanje mogu se identifikovati prema primenjenim režimima deviznog kursa i monetarne politike. Prva uključuje pomeranje ka suprotnoj strani deviznih aranžmana (sužavanje fleksibilnosti), tj. od fleksibilnog ka središnjoj formi ERM II. Nasuprot režimu deviznog kursa, koji će de facto biti izložen promenama $\mathrm{u}$ skladu sa progresom monetarne konvergencije, monetarni režim može biti zadržan $\mathrm{u}$ formi IT. Učestvovanje u ERM II podrazumeva održavanje target zone $u$ dvogodišnjem periodu, podrazumevajući targetiranje obe varijable deviznog kursa i inflacije - čineći time striktno 
IT neprihvatljivim. Simultano targetiranje kursa i inflacije veoma je komplikovano u okviru ERM II, te je u brojnim radovima istražena neodrživost ovog mehanizma (Adahl, 2000; Begg, Eichengreen, Halpern, Hagen \& Wyplosz, 2003; Fahrholz, 2003; Eijffinger, 2003; Issing, 2003; Polanski, 2004; Stavarek, 2004). Pomenuta kompleksnost je razlog zašto je prihvatljivije promeniti tip IT, pomerajući se od striktnog ka fleksibilnom (Orlowski, 2005). Poljska, Češka Republika, Mađarska i Rumunija prate razmatranu monetarnu putanju ka EZ, iako još uvek nisu pristupile ERM II. Slovačka je razmatranu monetarnu putanju pratila pre ulaska u EZ 2009.

Alternativni monetarni okvir druge faze monetarne konvergencije praktikovan je od strane zemalja bez značajne promene režima monetarne politike (targetiranje kursa) i režima kursa (valutni odbor ili konvencionalni fiksni evro-paritet). Kada bi ERM II bio rigidni mehanizam (a ne relativno fleksibilan kao što jeste), najznačajniju promenu bi osetila ova grupa zemalja. Slovenija, Estonija, Litvanija i Letonija su, prihvativši razmatrani okvir, beležile najslabije promene $\mathrm{u}$ monetarnoj politici, režimu kursa i mehanizmima prilagođavanja. Pomenute ekonomije su u trećoj fazi participiranja u EZ od 2007/2011/2014/2015. respektivno. Bugarska i Hrvatska su trenutno $\mathrm{u}$ drugoj fazi monetarne konvergencije (od 2007. i 2013. respektivno), ali još uvek nisu pristupile ERM II.

Dvogodišnje participiranje u ERM II, uz ispunjavanje ostalih kriterijuma iz Mastrihta, ukazuje da je ekonomska konvergencija dovoljno održiva i da je posmatrana ekonomija sposobna da funkcioniše unutar monetarne unije bez značajnih asimetrija, neravnoteža i teških prilagođavanja. ERM II obezbeđuje i informaciju o adekvatnom centralnom paritetu nacionalne valute u odnosu na evro, koji će biti neopoziv nakon ulaska u EZ. Međutim, esencijalna uloga uspostavljanja ERM II monetarnog aranžmana jeste priprema za funkcionisanje unutar monetarne unije. Nakon pristupanja EZ, zemlje članice ne mogu kontraciklično usmeriti monetarnu i politiku kursa kako bi izolovale svoje ekonomije od eksternih šokova. Nacionalne monetarne vlasti više ne mogu favorizovati slabljenje valute kako bi se stimulisale ekonomske (izvozne) aktivnosti i poboljšala eksterna (deficitna) pozicija. Uticaj na realnu ekonomiju i eksternu ravnotežu nakon pristupanja EZ može se ostvariti isključivo putem budžetskih i strukturalnih politika.

\section{TREĆA FAZA MONETARNE KONVERGENCIJE: MONETARNA UNIJA}

\section{Monetarni okvir}

Kao što je odluka o pristupanju ERM II kompleksna, isto važi i za odluku kada finalizirati monetarnu konvergenciju i prihvatiti evro. Mehanizam deviznog kursa II može predstavljati adekvatan okvir finaliziranja procesa konvergencije, ali je neophodno odabrati pravi momenat napuštanja ERM II i prihvatanja jedinstvene valute EZ. Fundamentalnim ekonomskim promenama prethodi analiza koristi i žrtava obe opcije, ERM II versus EMU (Ćorić \& Deskar-Škrbić, 2017). Relativno širok koridor od +/-15\% u ERM II obezbeđuje dovoljno monetarne fleksibilnosti kako bi se korigovale preostale razlike $\mathrm{u}$ realnim i nominalnim indikatorima. S druge strane, prihvatanje evra dovodi do niže premije rizika, nižih realnih kamatnih stopa i smanjenog rizika špekulativnih napada (Issing, 2003).

Koristi dužeg funkcionisanja unutar ERM II target zone mogu preovladati u poređenju sa ulaskom u monetarnu uniju. Duža participacija uključuje i koristi veće fleksibilnosti kursa (ograničena, ali još uvek prisutna, uloga kursa kao apsorbera šokova), pri prilagođavanju preostalih razlika $\mathrm{u}$ produktivnosti, nadnicama i inflaciji u poređenju sa EZ. Sa prihvatanjem evra, razlike se moraju neutralisati internom devalvacijom ili restriktivnim prilagođavanjem. Pomenuti mehanizam prilagođavanja je težak s obzirom da uključuje redukciju cena, nadnica i zaposlenosti, kako bi se povratila konkurentnost na sporiji i skuplji način (De Grauwe \& Schnabl, 2004). Kombinacija treće faze monetarne konvergencije je monetarna ne-autonomija i monetarna unija, kao rigidni režim deviznog kursa. 
Izbor i primena režima kursa i monetarne politike više se ne posmatraju u nacionalnom kontekstu.

Moguće je identifikovati dve grupe zemalja u ovoj fazi monetarne konvergencije: grupa sa radikalnijim, i grupa sa blažim promenama monetarne strategije. Prva monetarna putanja podrazumeva radikalnu transformaciju monetarnog režima i potpunu promenu nominalnog sidra u smislu prelaska od IT režima (sa značajnom monetarnom fleksibilnošću), ka rigidnom režimu monetarne unije (Belhocine, Crivelli, Geng, Scutaru, Wiegand \& Zhan, 2016). Pomenuta grupa zemalja prolazi kroz značajne promene režima kursa, jer se umesto ERM II target zone (sa širim marginama fluktuacije), neopozivo fiksira domaća valuta za evro, sa daljim napuštanjem nacionalne valute, politike deviznog kursa i monetarne politike. U razmatranu grupu zemalja se uključuju Slovačka od 2009, i u perspektivi Poljska, Češka Republika, Mađarska i Rumunija, s obzirom da pomenute članice EU nisu još uvek pristupile ERM II.

Druga monetarna putanja je praćena od strane zemalja sa manje izraženim transformacijama monetarnog režima (International Monetary Fund, 2015; Bakker, 2017). U pitanju je promena od deviznog kursa kao nominalnog sidra (sa nefleksibilnom monetarnom politikom), ka potpunom gubitku monetarne autonomije. Rigidni režim valutnog odbora i konvencionalni paritet se zamenjuju rigidnim režimom monetarne unije. Pomenuta promena je slabija, u poređenju sa prethodnom grupom zemalja, jer se visok stepen rigidnosti zamenjuje najvišim stepenom rigidnosti, odnosno, potpunim odricanjem od monetarnog suvereniteta. Promena mehanizama prilagođavanja u zemljama koje su targetirale kurs od samog početka tranzicije je nemerljivo slabija, imajući u vidu da date zemlje nisu ni osetile prednosti fleksibilne monetarne politike. Suštinski, razmatrane ekonomije su naviknute na inflatorno-deflatorni mehanizam prilagođavanja koji, takođe, preovladava unutar EZ. Promena je ipak, formalno, velika jer je monetarna politika izgubljena i ne postoji obaveza odbrane pariteta. Ovu monetarnu putanju pratile su Slovenija, Estonija, Letonija i Litvanija, koje su članice EZ od 2007, 2011, 2014 i 2015. respektivno.

\section{Izazovi emergentnih zemalja Evropske unije pod rigidnim monetarnim okruženjem}

Nezavisno od monetarnog okvira implementiranog na putu ka EZ, funkcionisanje unutar monetarne unije podrazumeva isključivi fokus na restriktivno prilagođavanje, jer devizni kurs više ne može služiti kao absorber šokova. Rigidnost restriktivnog prilagođavanja, u odsustvu redistributivnog prilagođavanja, posebno je došla do izražaja u emergentnim EU zemljama u kriznim okolnostima, posebno usled Velike recesije iz 2008. godine (Kang \& Shambaugh, 2014; Beker Pucar \& Srdić, 2018). Kao predstavnici dva suprotna monetarna okvira, uzimaju se Estonija, Litvanija i Letonija, s jedne strane (članice EZ), i Poljska, Češka Republika i Mađarska (članice EU), s druge strane. Slika 1 prikazuje inflacionu diferencu za pomenute ekonomije, dok Slika 2 prikazuje diference produktivosti i rasta BDP-a, $u$ poređenju sa EZ, u periodu 2000-2018. Slike prikazuju interne neravnoteže monetarnog (Slika 1) i realnog aspekta ekonomije (Slika 2).

Ukoliko se bliže razmotre dva aspekta interne ravnoteže, monetarni putem stope inflacije, i realni putem rasta BDP-a i produktivnosti, Slika 1 i Slika 2, nedvosmisleno ukazuju da su zemlje sa rigidnim režimom kursa i targetiranjem kursa (Baltičke zemlje), podložnije makroekonomskom pregrejavanju. Naime, inflatorna diferenca, diferenca rasta BDP-a i diferenca produktivnosti, u poređenju sa EZ u predkriznom periodu, najviše su izražene za Baltičke zemlje u poređenju sa Poljskom, Češkom Republikom i Mađarskom. Posledično, kao refleksija internog pregrejavanja, štedno/investicioni jaz kulminirao je pre krize (Slika 3 - leva strana), kao i deficit tekućeg bilansa (Slika 3 - desna strana).

Pomenute makroekonomske neravnoteže, interna (Slika 1 i Slika 2) i eksterna (Slika 3), kulminirale su pre Velike recesije iz 2008. Prema tome, interna i eksterna prilagođavanja su bila najoštrija za Baltičke zemlje $u$ post-kriznom periodu, posebno imajući $u$ vidu da u njima kurs ne apsorbuje eksterne šokove. Slika 4 pokazuje veće varijacije nominalnog deviznog kursa (NER) za grupu zemalja sa fleksibilnim 


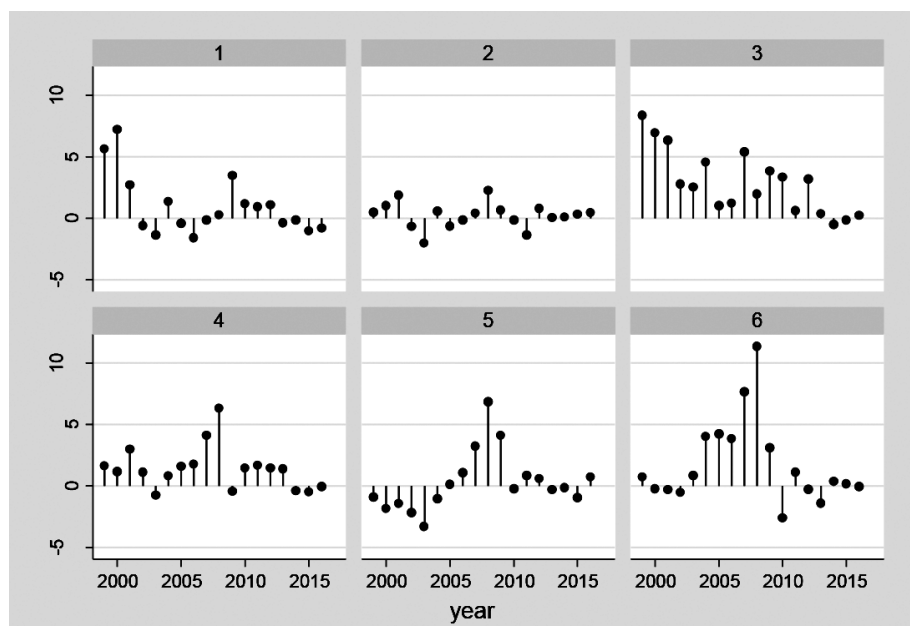

Napomene: 1-Poljska, 2-Češka Republika, 3-Mađarska, 4-Estonija, 5-Litvanija, 6-Letonija. Inflation difference - inflatorna (potrošačke cene, godišnje, procenat) diferenca - razlika između domaće stope inflacije i inflacije EZ. Godišnje vremenske serije nacionalne i EZ stope inflacije su preuzete iz IMF International Financial Statistics i WB World Development Indicators.

Slika 1 Inflaciona diferenca odabranih emergentnih zemalja EU u odnosu na EZ, u periodu 2000-2018.

Izvor: Autori
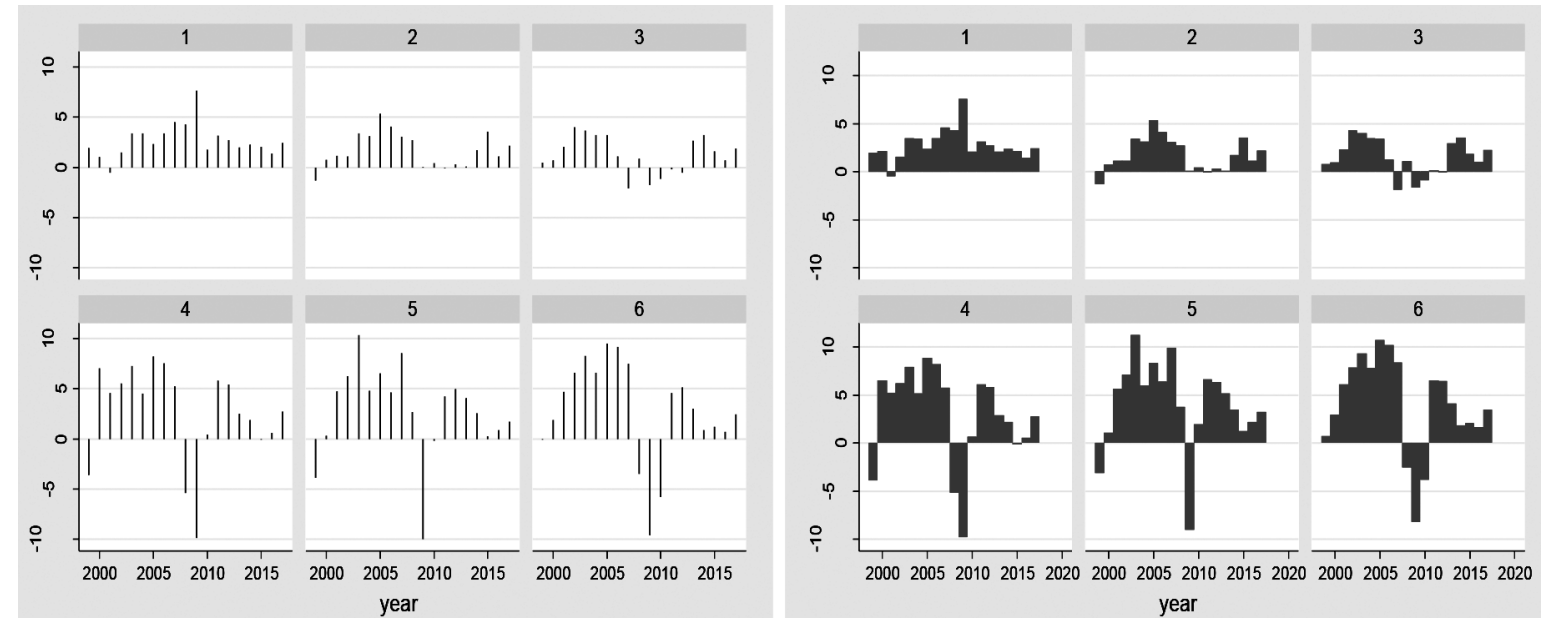

Napomene: 1-Poljska, 2-Češka Republika, 3-Mađarska, 4-Estonija, 5-Litvanija, 6-Letonija. GDP growth difference diferenca rasta BDP (godišnje, procenat) - razlika između nacionalnog rasta BDP i EZ. Productivity differential - diferenca produktivnosti (BDP/zaposlenost) - razlika između nacionalne varijable i varijable produktivnosti EZ. Godišnje vremenske serije rasta BDP, BDP i zaposlenosti, preuzete su iz IMF International Financial Statistics i WB World Development Indicators.

Slika 2 Diferenca rasta BDP i produktivnosti odabranih emergentnih zemalja EU u odnosu na EZ, u periodu 2000-2018. 
režimom (leva strana), u poređenju sa zemljama sa fiksnim režimom (desna strana). Jedina opcija za ove ekonomije je oštra interna devalvacija (restriktivno prilagođavanje), propraćena padom output-a i zaposlenosti (Slika 2), pod krizom indukovanim eksternim šokovima. Nasuprot tome, Poljska, Češka Republika i Mađarska na putu ka EZ mogu koristiti drugu, lakšu opciju prilagođavanja u vidu slabljenja valute, prolazeći manje turbulentan put ka EZ (Herrmann \& Jochem, 2013; Josifidis, Allegret \& Beker Pucar, 2014; Bakker, 2017). Poljska je najviše koristila kurs kao apsorber šokova sa najizraženijim varijacijama nominalnog deviznog kursa u grupi zemalja sa fleksibilnim režimima (Slika 4). U skladu sa pomenutom činjenicom, Poljska je jedina EEE koja nije osetila recesiju nakon izbijanja krize. Zahvaljujući slabljenju valute pod eksternim šokovima, Poljska je izbegla oštru internu devalvaciju. U grupi zemalja sa fiksnim režimima, Letonija je beležila izraženije korekcije nominalnog kursa (uglavnom devalvacije u pred-kriznom periodu), što je i očekivano jer ova ekonomija nije zvanično prihvatila valutni odbor kao Estonija i Litvanija.

Kao što slučaj emergentnih zemalja EU sa rigidnim režimom pokazuje, krucijalna žrtva je nemogućnost monetarnog kontracikličnog prilagođavanja i gubitak deviznog kursa kao apsorbera šokova u kriznim okolnostima. Isti mehanizam je prisutan i unutar monetarne unije $u$ smislu smanjene fleksibilnosti pri prilagođavanju asimetričnim šokovima. Prilagođavanja realnog deviznog kursa na asimetrične šokove se sprovodi kompletno kroz cene i nadnice, tj. putem interne devalvacije (Gibson \& Palivos, 2013). Kriza EZ iz 2010. ukazala je da nije jednostavno izvoditi pomenuta cenovna prilagođavanja bez prilagođavanja nominalnog kursa, posebno u nisko-inflatornom okruženju EZ. Nakon izbijanja krize u tako rigidnom okruženju, interna ravnoteža se narušava (rast nezaposlenosti i pad autputa) zbog stabilizacije eksterne pozicije. Uzevši u obzir asimetriju unutar EZ između jezgra i periferije, snažnije posledice eksternog prilagođavanja su očekivano zabeležile ranjive periferne zemlje. Svesne značajne žrtve pristupanja EZ, Poljska, Češka Republika i Mađarska još uvek nisu učestovale u ERM II. Odlaganje participacije često se posmatra kroz prizmu superiornosti ovih ekonomija tokom krize, $\mathrm{u}$ poređenju sa zemljama drugačijih monetarnih okvira (ali, takođe, i u poređenju sa slabijim članicama EZ), kao i kroz prizmu tekućih slabosti same EZ (Palankai, 2015).

S obzirom da se monetarna i politika kursa žrtvuju pristupanjem monetarnoj uniji, zemlje bi trebalo da razrade alternativne mehanizme prilagođavanja. Jedan od njih, naglašen unutar teorije optimalne valutne zone (Optimum Currency Area - OCA), predstavlja mobilnost radne snage i fleksibilno tržište rada (Mundell, 1961). Interna devalvacija u monetarnoj uniji je svakako teška, ali bi situacija bila još gora usled rigidnosti tržišta rada kao prepreke delovanju mehanizma internog prilagođavanja (Wood, 2014). Pomenuta rigidnost bi sprečila delovanje tržišnih snaga (rastuća nezaposlenost) u redukovanju nominalnih nadnica. Kao dodatak gore pomenutim preprekama, čak i da nominalne nadnice očekivano opadnu u skladu sa smanjenom zaposlenošću, postoji prepreka na relaciji između nadnica i cena domaćih proizvoda. Usled nedovoljne konkurencije na tržištima roba u pojedinim deficitnim ekonomijama, cena domaćih proizvoda ne opada simultano sa nominalnim nadnicama. Uopšteno govoreći, EZ nije kreirana kao OCA. Radna snaga je, uglavnom, imobilna zbog, mahom, jezičkih i kulturalnih barijera, kao i personalnih i socijalnih troškova migracije. Međutim, članice EU su trgovinski otvorene i integrisane, a kapital mobilan. Uprkos činjenici da EZ nije kreirana kao OCA ex ante, postoje indicije da se kreće u tom pravcu ex post (Rose, 2008; Furrutter, 2012).

\section{ZAKLJUČAK}

U radu se naglašavaju krucijalni izazovi na monetarnom putu emergentnih zemalja EU ka evro zoni (EZ). Progres ka monetarnoj uniji se posmatra kroz tri faze, počevši od faze pristupanja EU, potom faze pre pristupanja EZ, i konačno, participiranje u EZ na kraju procesa monetarne konvergencije. Emergentne evropske ekonomije (EEE) su prihvatale različite monetarne i strategije deviznog kursa, ali 

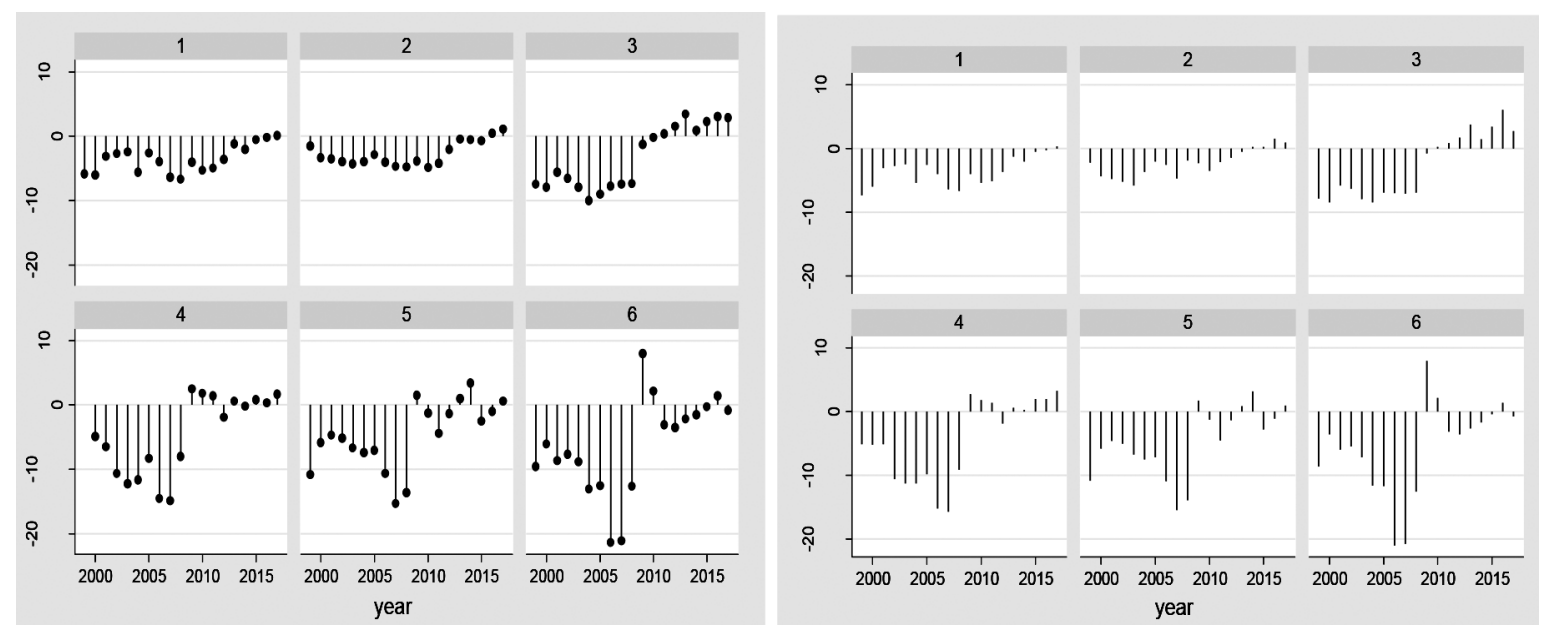

Napomene: 1-Poljska, 2-Češka Republika, 3-Mađarska, 4-Estonija, 5-Litvanija, 6-Letonija. Godišnje vremenske serije tekućeg bilansa (curent account balance) i štedno/investicionog jaza (saving/investment gap) preuzete su iz IMF International Financial Statistics i WB World Development Indicators.

Slika 3 Štedno/investicioni jaz i eksterna neravnoteža (tekući bilans kao \% BDP) odabranih emergentnih zemalja EU, u periodu 2000-2018.

Izvor: Autori

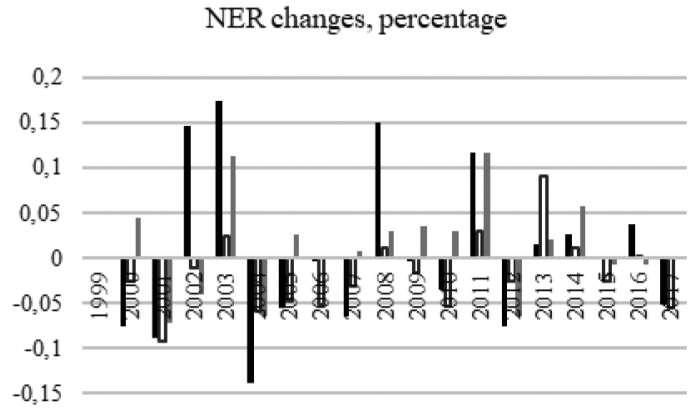

- POL $\square \mathrm{CZR}=\mathrm{HU}$

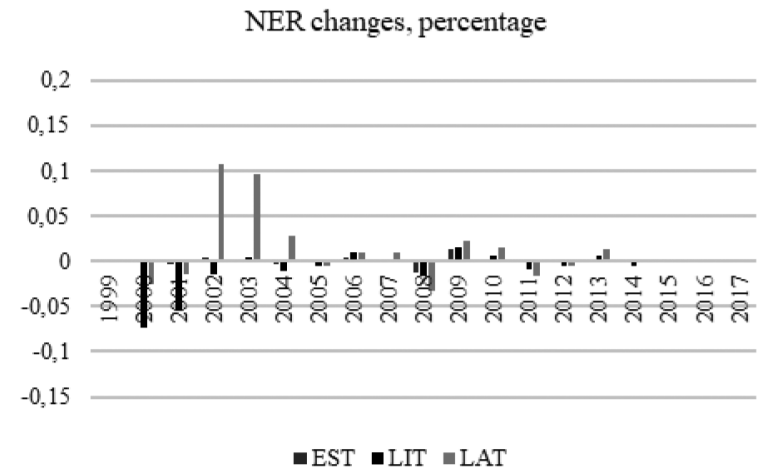

Napomena: POL - Poljska, CZR - Češka Republika, HU - Mađarska, EST - Estonija, LIT - Litvanija, LAT - Letonija. Godišnje serije nominalnog deviznog kursa (NER, domaća valuta u odnosu na evro, kraj perioda) preuzete su iz IMF's International Financial Statistics.

Slika 4 Varijacije nominalnog deviznog kursa (NER changes, percentage) u odabranim emergentnim zemljama EU sa fleksibilnim režimima (levo) i fiksnim režimima (desno), u periodu 1999-2017.

Izvor: Autori 
se fundamentalno izdvajaju dva različita monetarna pristupa. Jedan monetarni okvir podrazumeva targetiranje kursa kao monetarnog režima u kom kurs služi kao nominalno sidro, dok monetarna politika nije autonomna. U drugom monetarnom okviru se kombinuju inflaciono targetiranje (IT) sa fleksibilnim kursem. Dati okvir implicira da je kurs apsorber šokova, dok je monetarna politika slobodna za kontraciklično delovanje. Nezavisno od inicijalno implementiranog monetarnog okvira, EEE su nakon pristupanja EU, pre ili kasnije, u obavezi da participiraju u ERM II, target zoni sa ograničenom monetarnom autonomijom.

Postavljena hipoteza je ispitana na primeru dve grupe zemalja. Poljska, Češka Republika i Mađarska su članice EU u drugoj fazi monetarne konvergencije, koje oklevaju u vezi sa pristupanjem ERM II. Sužena monetarna fleksibilnost, svakako, je ključni razlog, imajući u vidu da su pomenute zemlje beležile bolje performanse pri udaru krize. Analizom krucijalnih makroekonomskih indikatora pomenutih zemalja, potvrđeno je da zemlje sa fleksibilnim režimima, generalno, beleže povoljnije performanse imajući u vidu interne i eksterne disbalanse u situaciji kada kurs apsorbuje eksterne šokove. Nasuprot tome, potvrđeno je da su Baltičke zemlje, kao primer emergentnih zemalja EU koje su pratile suprotnu monetarnu putanju, beležile dublje makroekonomske disbalanse, kao i oštrije interno i eksterno prilagođavanje $u$ post-kriznom periodu. Monetarna autonomija ovih zemalja je, svakako, limitirana jer su u pitanju male i otvorene ekonomije u kojima koristi prihvatanja evra dominiraju. S druge strane, Poljska, Češka Republika i Mađarska (kao i druge EEE koje su pratile njihovu monetarnu putanju ka EU i EZ), značajno gube u smislu monetarnog suvereniteta, dok inherentne slabosti EZ još više komplikuju donošenje odluke o pristupanju ERM II i EZ.

Shodno tome, kreatori integracione politike zemalja na putu ka EU i EZ trebaju imati na umu značajnu ekonomsku žrtvu produbljivanja monetarne integracije i potrebu pripremljenosti za funkcionisanje unutar rigidnog monetarnog okvira. Imperativ produbljivanja monetarne integrisanosti sa zemljama EZ predstavlja održiva nominalna i realna konvergencija zemalja članica. Bez obzira na zajednički monetarni okvir u trećoj fazi monetarne konvergencije, eksterna pozicija i prilagođavanje još uvek zavisi od individualnih makroekonomskih performansi članica EZ, kao i disciplinovanog korišćenja preostalih instrumenata ekonomske politike.

Uprkos identifikaciji generalnog okvira i naznaka u vezi sa predmetom istraživanja, buduća istraživanja bi trebalo usmeriti u pravcu analize pojedinačnih zemalja u izboru režima deviznog kursa i monetarne politike u razmatranim etapama monetarne konvergencije. Različite ekonometrijske tehnike, počev od VAR i VEC modela u okvirima analize vremenskih serija do nestacionarnih heterogenih panela, poželjno je primeniti u cilju daljeg rasvetljavanja izbora kreatora ekonomske politike individualnih emergentnih zemalja EU na putu ka EZ.

\section{REFERENCE}

Adahl, M. (2000). Accession countries' choice of exchange rate system in preparation for EMU. Retrieved March 05, 2019, from http://www.riksbank.se/upload/Dokument_riksbank/ Kat_publicerat/Artiklar_PV/er00_4_artikel3.pdf

Amerini, G. (2003). Exchange rates in the candidate countries. Statistics in focus, Economy and finance, Theme (2) - 39. Retrieved March 05, 2019, from http://edz.bib.unimannheim.de/www-edz/pdf/statinf/03/KS-NJ-03-039-ENN-EN.pdf

Bakker, B. B. (2017, March). Exchange rate regimes in emerging Europe. Paper presented at the $5^{\text {th }}$ Regional Meeting of Governers, Umag.

Backe, P., \& Thimann, C. (2004). The acceding countries' strategies towards ERM II and the adoption of the Euro: An analytical review. ECB Occasional Paper 10.

Beker Pucar, E., \& Srdić, S. (2018). Vulnerability of emerging Europe in external adjustment and financing mechanisms. RECEO, 49(3), 93-121.

Belhocine, N., Crivelli, E., Geng, N., Scutaru, T., Wiegand, J., \& Zhan, Z. (2016). Taking stock of monetary and exchange rate regimes in emerging Europe. IMF European department paper. 
Begg, D., Eichengreen, B., Halpern, L., Hagen, J., \& Wyplosz, C. (2003). Sustainable regimes of capital movements in accession countries. CEPR Policy Paper 10.

Bofinger, P. (2004). Exchange rate policies and institutional arrangements in the transition process to European Monetary Union. EUI Working Paper RSCAS 2004/17.

Ćorić, T., \& Deskar-Škrbić, M. (2017). Croatian path towards the ERM2: why, when and what can we learn from our peers? Ekonomski pregled, 68(6), 611-637.

De Grauwe, P., \& Schnabl, G. (2004). Exchange rate regimes and macroeconomic stability in Central and Eastern Europe. CESifo Working Paper 1182.

Eijffinger, S. C. W. (2003). Accession countries and ERM II. Briefing paper on "The conduct of monetary policy and an evaluation of the economic situation in Europe - 3rd quarter 2003 (August 2003)" for the European Parliament. Retrieved March 05, 2019, from http://www.europarl. europa.eu/comparl/econ/pdf/emu/speeches/20030910/ eifffinger.pdf

European Commission. (1998). Composite paper 1998. Retrieved March 05, 2019, from http://ec.europa.eu/enlargement/ archives/pdf/key_documents/1998/composite_en.pdf

Fahrholz, C. (2003). Strategic exchange-rate policy of accession countries in ERM II. Ezoneplus Working Paper 14. Retrieved March 05, 2019, from http://www.ezoneplus.org/archiv/ ezoneplus_wp_fourteen.pdf

Frenkel, J. A. (1999). No single currency regime is right for all countries and at all times. NBER Working Paper 7338.

Frommel, M. (2006). Volatility regimes in Central and Eastern European countries' exchange rates. Hannover Economic Papers (HEP) dp-333, Leibniz Universität Hannover, Wirtschaftswissenschaftliche Fakultät.

Furrutter, M. (2012). The Eurozone: The optimal currency area? IFIER papers 02/2012.

Gibson, H. D., \& Palivos, T. (2013). The crisis in the euro-area: An analytic overview. Special Conference Paper 28.

Herrmann, S., \& Jochem, A. (2013). Current account adjustment in EU countries: Does Euro-area membership make a difference? Discussion Paper 49/2013, Deutsche Bundesbank.
International Monetary Fund. (2015). Central and Eastern Europe: New member states (NMS) policy forum - Selected issues. Retrieved March 05, 2019, from http://www.imf.org/ external/pubs/ft/scr/2015/cr1598.pdf

International Monetary Fund. (2017). Annual report on exchange arrangements and exchange restrictions. Retrieved March 05, 2019, from https://www.imf.org/en/Publications/ Annual-Report-on-Exchange-Arrangements-and-ExchangeRestrictions/Issues/2018/08/10/Annual-Report-on-ExchangeArrangements-and-Exchange-Restrictions-2017-44930

Mundell, R. A. (1961). A Theory of optimum currency areas. The American Economic Review, 51(4), 657-665.

Issing, O. (2003). Considerations on monetary policy strategies for accession countries. Retrieved March 05, 2019, from http:// www.ecb.int/press/key/date/2003/html/sp030228.en.html

Josifidis, K., Allegret, J-P., \& Beker Pucar, E. (2011). Inflation targeting and exchange rate regimes in Serbia and selected transition economies. Eastern European Economics, 49(4), 88105. doi.org/10.2753/EEE0012-8775490405

Josifidis, K., Allegret, J-P., \& Beker Pucar, E. (2014). Adjustment mechanisms and exchange rate regimes in 2004 new EU members during the financial crisis. Post-Communist Economies, 25(1), 1-17. doi.org/10.1080/14631377.2013.756614

Kang, J-S., \& Shambaugh, J-C. (2014). Progress towards external adjustment in the euro area periphery and the Baltics. Working Paper 14/131, International Monetary Fund.

Nerlich, C. (2002, April). Exchange rate strategies of EU accession countries: Does exchange rate policy matter? Paper presented at the KOBE Research Seminar on Regional economic, financial and monetary co-operation: the European and Asian experience, Frankfurt.

Orlowski, L. T. (2005). Monetary policy adjustments on the final passage towards the euro. Center for Social and Economic Research, Warsaw. Retrieved March 05, 2019, from http:// www.case-research.eu/upload/publikacja_plik/4830919_ sa294ok.pdf

Palankai, T. (2015). The introduction of the euro and Central Europe. Economics and Sociology, 8(2), 51-69. doi:10.14254/2071- 789X.2015/8-2/5

Polanski, Z. (2004). Poland and the Euro zone enlargement: Monetary policy, ERM II, and other issues. Retrieved March 05, 2019, from http://www.defi-univ.org/IMG/pdf/23.pdf 
Rose, A. K. (2008). Is EMU becoming an optimum currency area? The evidence on trade and business cycle synchronization. Retrieved March 05, 2019, from http://faculty.haas.berkeley. edu/arose/emumetaecb.pdf

Stavarek, D. (2004). ERM II: Potential source of instability in the new EU-member countries. Retrieved March 05, 2019, from http://www-1.mtk.ut.ee/varska/2004/2_Rahapol_Finturud/ Stavarek.pdf
Schadler, S., Drummond, P., Kuijs, L., Murgasova, Z., \& van Elkan, R. (2005). Adopting the Euro in Central Europe Challenges of the next step in european integration. IMF Occasional Paper 234.

Wood, R. (2014). Eurozone macroeconomic framework: Reducing internal and external imbalances. MPRA Paper 53569 .

Primljeno 6. marta 2019, nakon revizije, prihvaćeno za publikovanje 17. aprila 2019. Elektronska verzija objavljena 25. aprila 2019.

Emilija Beker Pucar je vanredni profesor na Ekonomskom fakultetu u Subotici, Univerziteta u Novom Sadu, gde je doktorirala iz naučne oblasti Opšta ekonomska teorija i politika. Izvodi nastavu iz predmeta Međunarodna ekonomija, Međunarodne finansije, Makrometrija, Međunarodna makroekonomija na osnovnim, master i doktorskim akademskim studijama. Ključne oblasti naučnoistraživačkog interesovanja su ekonomske politike, sa fokusom na monetarnu politiku i režime deviznog kursa.

Olgica Glavaški je docent na Ekonomskom fakultetu u Subotici Univerziteta u Novom Sadu. Doktorirala je na Ekonomskom fakultetu Univerziteta u Beogradu, iz naučne oblasti Ekonomija. Izvodi nastavu iz predmeta Makroekonomija EU, Ekonomija javnog sektora, Makrometrija, Politička ekonomija evropskih integracija na osnovnim, master i doktorskim akademskim studijama. Ključne oblasti naučnoistraživačkog interesovanja su ekonomske politike, sa fokusom na fiskalnu politiku i održivost javne potrošnje. 


\title{
MONETARY STAGES AND FRAMEWORKS OF EMERGING EU MEMBERS
}

\author{
Emilija Beker Pucar and Olgica Clavaski \\ Faculty of Economics in Subotica, University of Novi Sad, Novi Sad, The Republic of Serbia
}

The paper reviews the monetary stages and frameworks towards the eurozone (EZ) for emerging EU members. At the first pre-EU stage, three monetary frameworks were identified, whereas at the second pre-EZ stage, the emerging EU members combined ER targeting with the rigid/fixed exchange rate regimes (ERRs), on the one hand, and inflation targeting (IT) with the ERM II, on the other. The last stage of monetary convergence assumes monetary nonautonomy within the monetary union as a rigid ERR, where the ER and monetary policies are sacrificed as countercyclical instruments. Countries with rigid ERRs are more prone to macroeconomic overheating, performing worse under a crisis impact compared to the floaters. The difficulties to maintain stability under a rigid ER environment, such as the monetary union, as well as the inherent vulnerabilities of the EZ, are crucial for the delayed entry of some EU members into the ERM II.

Keywords: eurozone, exchange rate mechanism, monetary convergence, adjustment mechanisms, monetary and exchange rate regimes

JEL Classification: E52, F15, F45 